\title{
Vertical structure of Antarctic tropospheric ozone depletion events: characteristics and broader implications
}

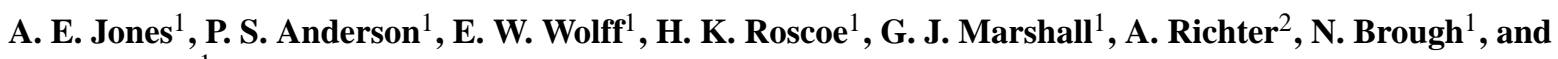 \\ S. R. Colwell ${ }^{1}$ \\ ${ }^{1}$ British Antarctic Survey, Natural Environment Research Council, High Cross, Madingley Road, Cambridge, CB3 0ET, UK \\ ${ }^{2}$ Institute of Environmental Physics, University of Bremen, Otto-Hahn-Allee 1, 28359 Bremen, Germany
}

Received: 2 March 2010 - Published in Atmos. Chem. Phys. Discuss.: 29 March 2010

Revised: 29 July 2010 - Accepted: 2 August 2010 - Published: 24 August 2010

\begin{abstract}
The majority of tropospheric ozone depletion event (ODE) studies have focussed on time-series measurements, with comparatively few studies of the vertical component. Those that exist have almost exclusively used freeflying balloon-borne ozonesondes and almost all have been conducted in the Arctic. Here we use measurements from two separate Antarctic field experiments to examine the vertical profile of ozone during Antarctic ODEs. We use tethersonde data to probe details in the lowest few hundred meters and find considerable structure in the profiles associated with complex atmospheric layering. The profiles were all measured at wind speeds less than $7 \mathrm{~ms}^{-1}$, and on each occasion the lowest inversion height lay between $10 \mathrm{~m}$ and $40 \mathrm{~m}$. We also use data from a free-flying ozonesonde study to select events where ozone depletion was recorded at altitudes $>1 \mathrm{~km}$ above ground level. Using ERA-40 meteorological charts, we find that on every occasion the high altitude depletion was preceded by an atmospheric low pressure system. An examination of limited published ozonesonde data from other Antarctic stations shows this to be a consistent feature. Given the link between $\mathrm{BrO}$ and ODEs, we also examine ground-based and satellite $\mathrm{BrO}$ measurements and find a strong association between atmospheric low pressure systems and enhanced $\mathrm{BrO}$ that must arise in the troposphere. The results suggest that, in Antarctica, such depressions are responsible for driving high altitude ODEs and for generating the large-scale $\mathrm{BrO}$ clouds observed from satellites. In the Arctic, the prevailing meteorology differs from
\end{abstract}

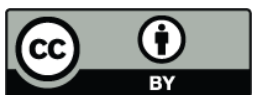

Correspondence to: A. E. Jones (aejo@bas.ac.uk) that in Antarctica, but, while a less common effect, major low pressure systems in the Arctic can also generate $\mathrm{BrO}$ clouds. Such depressions thus appear to be fundamental when considering the broader influence of ODEs, certainly in Antarctica, such as halogen export and the radiative influence of ozone-depleted air masses.

\section{Introduction}

The remarkable behaviour exhibited by tropospheric ozone during spring in both polar regions is well documented (see Simpson et al., 2007 for full overview). Concentrations of ozone can fall from background levels to below instrumentation detection limits and remain suppressed for timescales of the order of hours to days. These excursions are observed sporadically from coastal locations, and are widely referred to as tropospheric ozone depletion events (ODEs). The ozone depletion is driven by halogen chemistry, most notably bromine, which has a source associated with the sea ice zone (e.g. Neuman et al., 2010). The exact source(s) and mechanisms responsible for bromine-release are still subject to debate, but the combination of concentrated sea salt in a condensed phase substrate appears to be a pre-requisite. Under these conditions, and with sufficient acidity, gaseous $\mathrm{HOBr}$ can react with sea salt bromide within the condensed phase and generate $\mathrm{Br}_{2}$ that is then released to the atmosphere. Subsequent photolysis of this $\mathrm{Br}_{2}$ generates $\mathrm{Br}$ radicals that can react with and destroy $\mathrm{O}_{3}$. The $\mathrm{BrO}$ thus formed can then react with $\mathrm{HO}_{2}$ to form $\mathrm{HOBr}$. Altogether, this process is referred to as the "Bromine Explosion" (Fan and Jacob, 1992; Tang and McConnell, 1996; Vogt et al., 1996; Lehrer et al.,

Published by Copernicus Publications on behalf of the European Geosciences Union. 
2004). Environmental, as well as chemical conditions are also critical for ODEs. Various studies have suggested a role for temperature in driving ODEs (Tarasick and Bottenheim, 2002; Jacobi et al., 2006) although this influence remains debated (Bottenheim et al., 2009). The role played by meteorology has also been highlighted, with a critical influence both on the onset of ODEs and on their termination (e.g. Hopper and Hart, 1994; Jones et al., 2006, 2009; Morin et al., 2005).

Surface ozone has been measured at a relatively large number of coastal research stations in both the Arctic and Antarctica (Helmig et al., 2007), and these data have been used in the majority of ODE studies. Recently, measurements of surface ozone over the frozen Arctic Ocean have been carried out from ships (Jacobi et al., 2006; Bottenheim et al., 2009). In particular the Bottenheim et al. study has demonstrated the capability for really sustained ozone depletion within the sea ice zone. We note that ship-borne $\mathrm{BrO}$ measurements have also been carried out (Wagner et al., 2007; Pöhler et al., 2010).

However, ODEs are 4-dimensional phenomena, with structure in the horizontal and vertical components as well as in time. Relatively few measurements have been made of the vertical profile of ozone, given the demands of such a procedure. Those that exist, however, have revealed important information. For example, it appears that ozone depletion generally extends from the surface up to a few $100 \mathrm{~s}$ of meters, but that occasionally depletion to a few kilometres is observed (Solberg et al. 1996; Friess et al., 2004; Bottenheim et al., 2002; Strong et al., 2002; Tarasick and Bottenheim, 2002; Ridley et al., 2003; Wessel et al., 1998). Sometimes ozone depleted air can be observed at several kilometres altitude while ozone at the surface is normal (Wessel et al., 1998; Roscoe et al., 2001). Further, the vertical extent of an ODE appears to be strongly modulated by the physical behaviour of the atmosphere, with temperature inversions forming the upper boundary of depleted air masses (e.g. Wessel et al., 1998; Strong et al., 2002; Tarasick and Bottenheim, 2002).

The studies referenced above were all carried out using ozonesondes on free-flying balloons. These balloons and their payload access the ozone profile throughout the whole of the troposphere providing information on, for example, the height to which ODEs extend. They are highly effective at providing the broad vertical picture. However, the balloons rise rapidly so that, with the ozone sonde time constant $(\sim 100 \mathrm{~s})$, the ozone profile is considerably smoothed in the vertical. As a result, much of the detail in the profile is not accessible. An alternative to a free-flying system is offered by tethered platforms, such as blimps. They are limited in height by the additional weight of the tether line, but tethered platforms enable slow controlled vertical ascent and descent rates. They thus enable significantly enhanced measurement resolution with vastly increased detail in the ozone profile information. Only two tethersonde studies of springtime tropospheric ozone have previously been reported. In the first, one Arctic ODE was probed in detail (Anlauf et al.,
1994). The data, presented at a resolution of $\sim 17 \mathrm{~m}$, show a thermally-neutral layer depleted in ozone whose growth with height was controlled by an inversion. In the second, the ozone measurements were used to explore the vertical extent of snowpack and halogen chemistry in the Arctic (Tackett et al., 2007). No tethersonde measurements of ODEs have previously been made in Antarctica.

There is thus considerable merit in both profiling techniques, with each revealing different, but complementary, information.

In terms of data coverage, the overriding majority of ozone profiling studies published to date have been carried out in the Arctic. Thus far, only one study using ozonesondes to focus on the Antarctic troposphere has been published (Wessel et al., 1998), and a few profiles measured from ongoing launch programmes at Neumayer and McMurdo stations have been used as supporting data (Kreher et al., 1997; Roscoe et al., 2001; Frieß et al., 2004).

In this paper we analyse data from two separate field experiments and use the results to explore the characteristics and implications of low- and high-altitude tropospheric ozone depletion events. The first, a tethersonde experiment carried out in spring 2007, allows us to probe details in the lowest few hundred meters of the ozone profile and to explore the influence of the complex layering within this region of the atmosphere. The second was a programme of free-flying ozonesondes that was carried out at Halley during austral spring 1987. The experiment was aimed at measuring profiles of stratospheric ozone, and the observations made in the troposphere have not previously been analysed. The data enable us to select cases of high altitude ozone depletion (i.e. extending of the order 1 to $\sim 3 \mathrm{~km}$ above ground level) as a starting point for teasing out mechanisms driving ODE chemistry on wider spatial scales. The combined results enable us to move towards a generalised picture of ODEs in Antarctica and assess their implications and the challenges for modelling them both on local and regional scales.

\section{Location}

The measurements reported here were made at the British Antarctic Survey station, Halley, in the Weddell Sea sector of coastal Antarctica (Fig. 1). The tethersonde experiment of 2007 was carried out at Halley V station $\left(75^{\circ} 35^{\prime} \mathrm{S}\right.$, $26^{\circ} 34^{\prime} \mathrm{W}$ ) while the free-flying ozonesondes of 1987 were launched at the previous, but nearby Halley IV station $\left(75^{\circ} 36^{\prime} \mathrm{S}, 26^{\circ} 42^{\prime} \mathrm{W}\right)$.

Halley sits on the floating Brunt Ice shelf, $32 \mathrm{~m}$ above sea level. The surrounding area is snow-covered, but flat and featureless, with the nearest rock outcrops roughly $200 \mathrm{~km}$ away. Halley is roughly $15 \mathrm{~km}$ inland from the permanent ice edge, and as the coast effectively forms a promontory at this point, the station is close to the Weddell Sea in three directions. During springtime, the Weddell Sea is extensively 


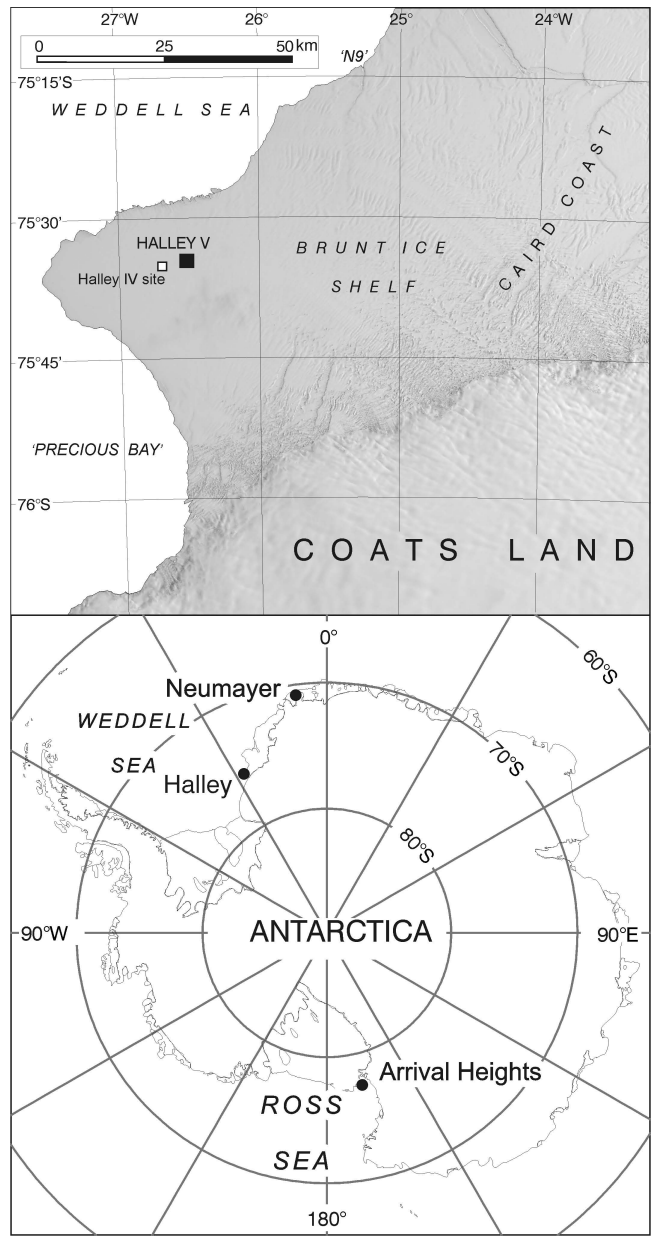

Fig. 1. Maps showing location of Halley station as well as other locations referred to in the paper.

covered in ice, interspersed with open water leads, of note being a large polynya to the south west of Halley known as Precious Bay (Anderson, 2003). To the east of Halley is the inland ice, and indeed, the prevailing wind direction at Halley is easterly. Beyond the grounding line to the south east of Halley, continental ice rises to the polar plateau. Katabatic winds from the plateau descend towards Halley, but remain aloft of the station, above a cold pool below (Renfrew et al., 2002). For a significant amount of the time during spring, air arrives at the base from across the sea ice zone. There is thus a range of air masses with different histories in the vicinity of Halley. Year-round measurements of $\mathrm{BrO}$ (as well as numerous other trace gases) were performed at Halley during the 2004/05 CHABLIS (Chemistry of the Antarctic Boundary Layer and the Interface with Snow) campaign (Jones et al., 2008). The measurements, made using a long-path DOAS, revealed a springtime maximum, with highest mixing ratios observed when air had been over the sea ice within the previous 24 hours, but still present up to $6 \mathrm{pptv}$ in air that had spent at least 4 days over the continent (Saiz-Lopez et al., 2007). Subsequent modelling studies (Saiz-Lopez et al., 2008) suggested that $\mathrm{BrO}$ ought to be well mixed within a $200 \mathrm{~m}$ springtime boundary layer.

\section{Methodology}

\subsection{The 2007 tethersonde study}

A variety of instruments and techniques were used during the 2007 experiment with measurements for surface ozone, ground-based routine meteorology, sondes for measuring profiles of ozone and temperature, and an acoustic radar that highlights layers of atmospheric turbulence and thus provides considerable context for the profile data. Ideally, profiles of ozone would be measured on a continuous basis, in order to provide maximum information. However, as tethersonde experiments are highly labour-intensive, it was necessary instead to make targeted measurements. This was achieved using the surface ozone monitor: when a rapid decline in surface ozone mixing ratios was measured, an alarm triggered which alerted the overwintering staff to the onset of an event and the chance to initiate a profiling experiment. It is worth noting that such tethered profiling work can only be carried out at relatively low wind speeds, so that all the ODEs probed using this method occurred at Halley at wind speeds less than $7 \mathrm{~ms}^{-1}$.

\subsubsection{Surface ozone and routine meteorology}

Measurements of wind speed and direction are carried out on a routine basis at Halley. The anemometers and wind vanes are located near to the main station, at a height roughly $10 \mathrm{~m}$ above the snow surface. The data have an accuracy of about $0.5 \mathrm{~ms}^{-1}$ for wind speed and $5^{\circ}$ for wind direction (KönigLanglo et al., 1998) and are available at 1-min resolution.

Surface ozone was measured at the Halley Clean Air Sector Laboratory (CASLab), which is located roughly $1 \mathrm{~km}$ south east of the station generators, and in a sector that receives minimal contamination from the base (Jones et al., 2008). Surface ozone was measured year-round during 2007 using a Thermo Electron Corp. model 49C. The instrument uses a UV absorbance technique and has a detection limit of $1 \mathrm{ppbv}$ (parts per billion by volume) and a precision of $1 \mathrm{ppbv}$ for 1-min averages of 10-s data.

\subsubsection{Blimp profiling system}

In order to provide detail in the very lowest region of the atmosphere, we employed a tethered AB400 blimp (Cameron Balloons Ltd) as the airborne platform, which allowed a controlled and variable ascent/descent rate. The blimp was able to carry a payload of $\sim 2 \mathrm{~kg}$ (in addition to the tether line) and was made of lightweight fabric (LAM30) that had been used successfully in previous profiling experiments carried out at low temperatures (Rankin and Wolff, 2002). The blimp 
had an internal volume of $11.3 \mathrm{~m}^{3}$, and was stored inflated inside a $4 \mathrm{~S}$ Weatherhaven between experiments. A single reel (1000 m length) of $2 \mathrm{~mm}$ diameter Dyneema SK75 performance cord (Dynamic) (English Braids Ltd) was used as the tether line, providing a balance between tensile strength (900 kg breaking load) and weight. The ascent/descent rate for the blimp was usually between 0.03 and $0.15 \mathrm{~ms}^{-1}$ (maximum $0.25 \mathrm{~ms}^{-1}$ ), which, with the time constant of the ECC sonde (see below), yielded a vertical measurement resolution of between 4 and $19 \mathrm{~m}$ (varying from flight to flight) with a mean of $11 \mathrm{~m}$.

\subsubsection{Vertical profiles of ozone and temperature}

Ozone was monitored using an electro-chemical cell (ECC) sonde (Komhyr, 1969, 1995). The sondes were Science Pump Corp. Model 5A, with customised electronics, powered by three $9 \mathrm{~V}$ lithium cells in parallel. No correction was required for reduction in pump speed with height given that these were tropospheric measurements. However, below a battery voltage of $2.9 \mathrm{~V}$, the pump voltage would fluctuate, resulting in fluctuating pump speeds. Data were therefore rejected once the battery voltage dropped below $2.9 \mathrm{~V}$. The other calibration factors vary by a few percent depending on the concentration of KI and buffers, but the calibration is otherwise close to absolute (standard formula given by Komhyr et al., 1995). For tropospheric measurements, where the partial pressure of ozone is small, errors in calibration are generally small compared to errors in determining the zero of the measurement (see below).

Before a flight, a sonde was prepared and the output signal checked using an ozoniser set to deliver about $50 \mathrm{ppbv}$. The zero was checked by sampling through an active charcoal filter - if zero did not stabilise to within a few tens of $\mathrm{mV}$ of the zero of the electronics $(250 \mathrm{mV})$ within $10 \mathrm{~min}$, the sonde was set aside and another prepared. The zero was again checked outside before a flight.

The ozonesonde signal was transmitted to the ground via external inputs to a custom-made meteorological sonde. The meteorological sonde included a wind vane, a radio transmitter (Radiometrix, $10 \mathrm{~mW}$ at $173 \mathrm{MHz}$ ), a temperature compensated pressure sensor (Vaisala PTB100B, resolution $0.1 \mathrm{hPa}$ ), a temperature sensor (Betatherm 1K7A329I, accuracy $0.2 \mathrm{~K}$ ), and 3 rotating wind cups on a near-vertical axis with rotating disc and optical counter sampling speed for $1 \mathrm{~s}$ intervals. It also included a tilt compensated 3 -axis compass (Honeywell HMR3300), incorporating a 2-axis accelerometer allowing for up to $60 \mathrm{deg}$ pitch and roll - this yielded wind direction, the sonde being fixed relative to the wind by its wind vane. The sonde used a microcontroller (Parallax STAMP II) and a 14-bit digitiser with 8 channel multiplexer (AD7856). Sensors were sampled once every $10 \mathrm{~s}$ before powering the transmitter for a few $\mathrm{ms}$ to transmit data, a procedure that avoided RF interference to the sensor signals. The meteorological sonde was powered by a single $9 \mathrm{~V}$ lithium primary cell, which lasted many flights because of the small duty cycle of the transmitter.

The height of the sonde was subsequently calculated from the hydrostatic equation, and the ozone mixing ratio adjusted for the ozonesonde time constant (previously determined to be $100 \mathrm{~s}$ ).

\subsubsection{Sodar}

A single axis, vertically pointing monostatic acoustic sounder (sodar) was used to gain qualitative information about the physical structure of the lowest $600 \mathrm{~m}$ of the atmosphere. This technique has been used in a previous study at Halley and is more fully described elsewhere (Anderson, 2003; Jones et al., 2006). In brief, 10-s profiles of echo intensity are displayed as time-height images, or echogrammes, that indicate the intensity of atmospheric turbulence within a stratified atmosphere. Lack of echo can arise either from lack of stratification, or lack of turbulence, so an exact interpretation is not possible. However, some known features of the lower atmosphere are visible. For example, the echogrammes from Halley often reveal multiple horizontal layering within the lower atmosphere which correlates with changes in the vertical potential temperature gradient (more or less positive) (Anderson, 2003). The echogrammes also include signals of convection, and "fossil convection". Fossil convection refers to the residual signal after convection is no longer active and can be explained as follows. During convection, plumes of warm air rise from the surface. At the edge of these plumes there is both a temperature gradient and shear-generated turbulence, the combination of which generates strong sodar echo return. If the source of surface heating is removed, this echo structure takes some time ( $\sim$ hour) to diffuse and disperse. Hence, although the convection is dead, the sodar registers a blurred after-effect, described as "fossil" convection (Culf, 1989).

The sodar used in this experiment was not able to probe the atmosphere below $\sim 20 \mathrm{~m}$ height due to ringing of the antennae, and the solid apparent echo shown in the figures is spurious. Spurious echoes are also generated by surface winds in excess of $8 \mathrm{~ms}^{-1}$ as these cause wind noise around the sodar antenna guy-lines. Finally, noise can be generated by people working near the antenna which is visible as thin vertical strips in the echogramme.

\subsection{The 1987 free-flying ozonesonde system}

A programme of ozonesonde flights was conducted at Halley IV during 1987 in order to study stratospheric ozone depletion (Gardiner and Farman, 1988). ECC mark 3A sondes (Science Pump Corp.) were used to determine partial pressures of ozone at various heights and were operated according to Komhyr (1986). The ECC sondes were linked to VIZ $403 \mathrm{MHz}$ radiosondes which transmitted the data back to the station. After a flight, the ozonesonde calibration was 
checked with a Dobson spectrophotometer measurement if available. Data were transmitted every $20 \mathrm{~s}$, which, with an ascent rate of roughly $5 \mathrm{~ms}^{-1}$ yielded a vertical resolution of about $100 \mathrm{~m}$. Data were stored at standard pressure levels and at significant levels in the ozone profile, resulting in irregularly spaced vertical grids. Ozonesonde launches began in mid April and continued until late November. For the majority of that time, sondes were launched every ten days or so, but from early August until late October they were launched roughly every 1 to 3 days, depending partly on weather conditions. They were released on a routine basis at approximately the same time on each launch day ( 16:00 GMT). There were no surface ozone observations at Halley in 1987 so we have only a 1-point measurement at ground level on the days with launches and no information at all on days with no ozonesonde launches - a fact that becomes important when analysing the results.

\section{Results}

\subsection{The 2007 tethersonde study}

During the 2007 austral spring, six tethersonde flights were achieved, with surface air masses in each case approaching Halley from the west or south-west (see Fig. 2b), i.e. across the sea ice zone and/or Precious Bay. The wind speeds during each flight ranged from $1 \mathrm{~ms}^{-1}$ to $7 \mathrm{~ms}^{-1}$ (see Fig. 2c), so all cases probed were relatively low wind speed ODEs. The timing of each flight relative to the condition of surface ozone is shown on Fig. 2a, and it is clear that launches were carried out during all stages of an ODE, i.e. during onset (24 August 2007, 2 September 2007-flight a, 7 September 2007), at totality (21 August 2007), and during termination (25 August 2007, 2 September 07-flight b). The profiles of $\mathrm{O}_{3}$ and potential temperature measured during each experiment are shown in plots A and B of Figs. 3 to 8. Plot C of each figure shows the flight track of the tethersonde superimposed on the sodar trace to show the different air masses encountered by the sonde. Plot $\mathrm{D}$ shows the corresponding time-series of $\mathrm{O}_{3}$ and potential temperature measured along the flight track. Data were filtered according to battery voltage; once the voltage started to drop, data were removed, so the amount of data recorded varies with each flight. As such data have not previously been assembled we examine them in some detail on a case by case basis.

ODEs are often referred to as boundary layer events, with the boundary layer top, or "inversion", acting as the lid to the depletion. Indeed, an inversion is classically defined as the region of the boundary layer where the potential temperature gradient is positive. However, in polar regions, this becomes problematic. A key feature of polar regions during winter and spring is the persistent, deep, continually stratified lower atmosphere that is characterised by a positive temperature gradient throughout (Anderson and Neff, 2008). Within such

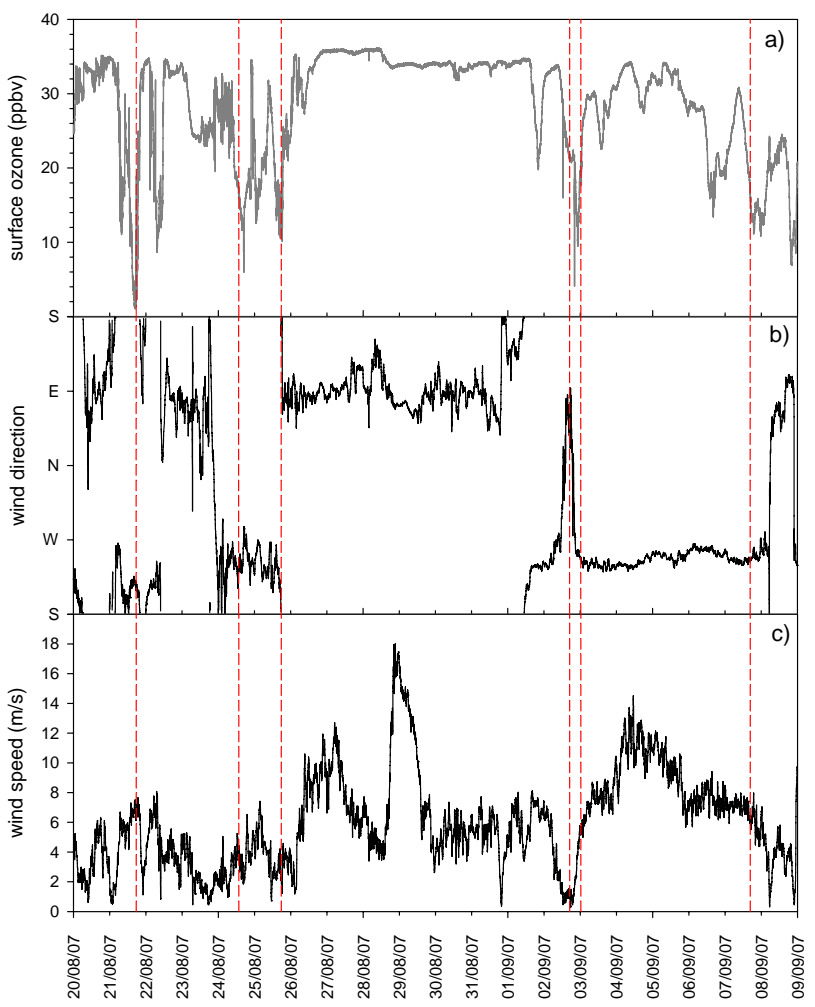

Fig. 2. Timeseries of (a) surface ozone, (b) wind direction, and (c) wind speed measured during the period of the tethersonde profiling experiments. The red lines indicate the mid-point of the tethersonde profiling experiments.

a layer there is no inversion in the classical sense, and so no obvious upper limit to the boundary layer based on temperature structure alone. For this reason, when presenting the tethersonde data we discuss atmospheric layering primarily in terms of the vertical potential temperature gradient, $\frac{\partial \theta}{\partial z}(z)$, and also the mixing height. The former gives an indication of atmospheric stratification, and the latter the height to which mixing can be expected. To further assess degrees of mixing we calculate the Richardson number $(R i)$ when data quality allows. $R i$ is a measure of the balance between turbulence generation (by wind shear) and turbulence suppression by stratification (i.e. potential temperature gradient), and is defined as:

$R i=\frac{g}{T} \frac{\partial \theta / \partial z}{(\partial U / \partial z)^{2}}$

where $U$ is the wind speed, $g$ is the acceleration due to gravity $\left(=9.81 \mathrm{~ms}^{-2}\right), T$ is ambient temperature $(\mathrm{K}) . R i$ is thus a measure of stability (and hence degree of mixing) within an air mass; small $R i$ (large shear and small stratification) implies strong turbulence and hence strong vertical mixing; large Ri implies suppression or even absence of turbulence, and hence low or zero mixing. Traditionally, a critical value 
of $R i=0.25$ is taken to be the transition from one regime to the other (Stull, 1988), although fluxes (and hence turbulence) are still observed in the environment at super-critical $R i$ (Galperin et al, 2007). As $R i$ is based on gradients it is sensitive to measurement error, especially winds, and the relatively short sample time of $U$ at each level means the $R i$ estimate will have error of up to $50 \%$.

\subsubsection{Profile experiment 21 August 2007}

During the flight of 21 August 07, ozone was almost completely depleted in a layer extending from ground level to $\sim 30 \mathrm{~m}$ (Fig. 3b). This layer was characterised by a strong gradient in potential temperature, $\frac{\partial \theta}{\partial z}$, i.e. was highly stratified, and $R i$ within this layer was $\sim 0.4$, indicating intermittent or limited mixing. Between $30 \mathrm{~m}$ and $40 \mathrm{~m}$ there is a clear discontinuity in both $\mathrm{O}_{3}$ and $\theta$, and above this discontinuity, little change in either $\mathrm{O}_{3}$ or $\theta$ is visible up to the $175 \mathrm{~m}$ range of this flight. For the region from $40 \mathrm{~m}$ to 120 $\mathrm{m}$, it is possible to calculate $R i$. Even though $\frac{\partial \theta}{\partial z}$ is small (see Fig. 3a), $R i$ is large (>1.4) driven by the very weak wind shear (not shown). The result implies that this region of the atmosphere is laminar and that mixing is negligible.

The sodar echogramme (Fig. 3c) shows little in the way of air mass structure above $40 \mathrm{~m}$. Below $40 \mathrm{~m}$, the echogramme shows a strong continual echo between $30 \mathrm{~m}$ and $40 \mathrm{~m}$. Within the lowest $30 \mathrm{~m}$ there is evidence of residual structure, likely to arise from fossil convection (see Sect. 3.1.4).

The atmosphere thus appears to be split into two masses; a depleted layer extending from the surface to $\sim 30 \mathrm{~m}$ and a layer above $\sim 40 \mathrm{~m}$ with background ozone mixing ratios. Between is a transition region some $10 \mathrm{~m}$ deep.

During descent, no structure is evident in either $\theta$ or $\mathrm{O}_{3}$ until the sonde reaches the region of fossil convection (Fig. 3c and d), when small scale structure is again evident in both. The ozonesonde battery voltage dropped just after the instrument had once again entered the transition region, so below this altitude data have been filtered out.

\subsubsection{Profile experiment 24 August 2007}

During this flight, the ground-based surface ozone measurements (Fig. 2a) show that ozone was only partially depleted and that the ODE was still developing. The profile in potential temperature (Fig. 4a) shows a well-defined and extremely shallow layer extending from the ground to $\sim 10 \mathrm{~m}$ height. This layer is also visible in the sodar echogramme (Fig. 4c) which, after some initial wind noise, shows a shallow $(\sim 20 \mathrm{~m})$ near-surface turbulent layer which decreases in height during the flight. Interestingly, there is no equivalent discontinuity in ozone visible from the sonde profile (Fig. 4b). According to these data, ozone mixing ratios were depleted, but roughly constant from the surface to a height of $\sim 80 \mathrm{~m}$, and above this altitude, mixing ratios gradually returned to background amounts. The potential temperature

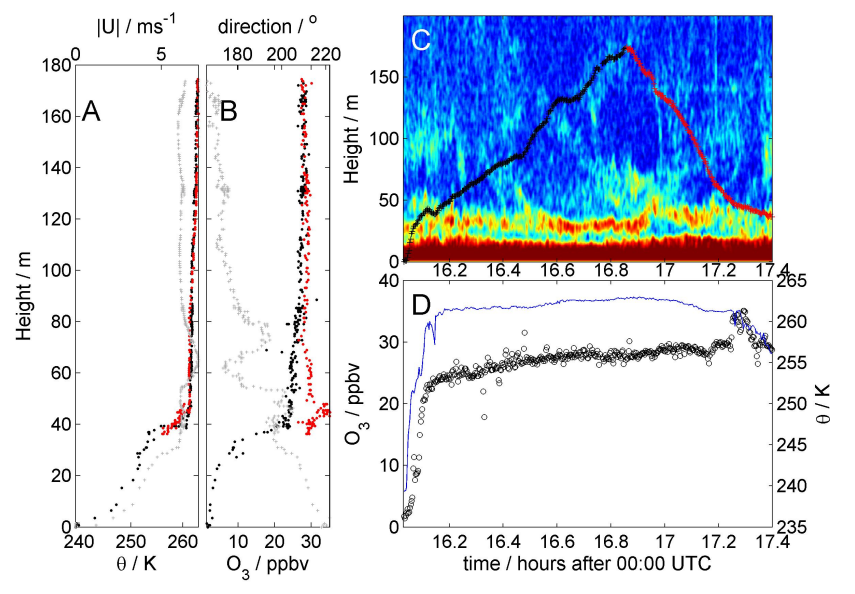

Fig. 3. Tethersonde profiling experiment of 21 August 2007. (A) profile of potential temperature $(\theta)$ (black = ascending flight; red $=$ descending) with wind speed during ascending flight shown in grey; $(\mathbf{B})$ profile of ozone (black = ascending flight; red = descending) with wind direction during ascending flight shown in grey; (C) sodar trace which shows, using a false-colour scale, how structure within the atmosphere develops with time - the flight path of the blimp is shown by the black and red lines; (D) measurements of ozone (circles) and potential temperature (blue line) plotted against time. By comparing (C) and (D) it is possible to see at what altitude, and in which air mass, measurements of ozone and $\theta$ were made.

data show that above the 10-m discontinuity, the atmosphere is stratified throughout, and indeed, there is no turbulence signal on the sodar echogramme.

Our interpretation of these data is that a relatively warm air mass, already depleted in ozone, was transported across the sea ice zone towards Halley. As it traversed the ice shelf, the heat from the air mass was absorbed by the radiativelycooled snow surface, generating the strong gradient in potential temperature. The rate of ozone depletion, however, was not affected, so the signals in ozone and potential temperature are effectively decoupled.

\subsubsection{Profile experiment 25 August 2007}

The flight of 25 August 2009 revealed more complex vertical profiles, with three distinct air masses probed. The greatest ozone depletion was evident in the well-defined and highlystratified layer that extended to $\sim 20 \mathrm{~m}$ above the ground (Fig. 5a and b). Heat was flowing down a thermal gradient from the atmosphere into the radiatively-cooling snow surface below at about $5 \mathrm{Wm}^{-2}$ as measured by a sonic anemometer at $4 \mathrm{~m}$ (not shown). Ozone mixing ratios increased to between 15 and $20 \mathrm{ppbv}$ in the region between $\sim 20 \mathrm{~m}$ and $\sim 80 \mathrm{~m}$ while $\partial \theta / \partial z$, although small, remained positive (indicating stratification). From $\sim 80 \mathrm{~m}$ to $\sim 100 \mathrm{~m}$, a transition zone is evident, characterised by an increase in stratification $\left(\partial \theta / \partial z=0.08 \mathrm{Km}^{-1}\right)$, and within which ozone mixing ratios increased rapidly. The sodar data (Fig. 5c) 

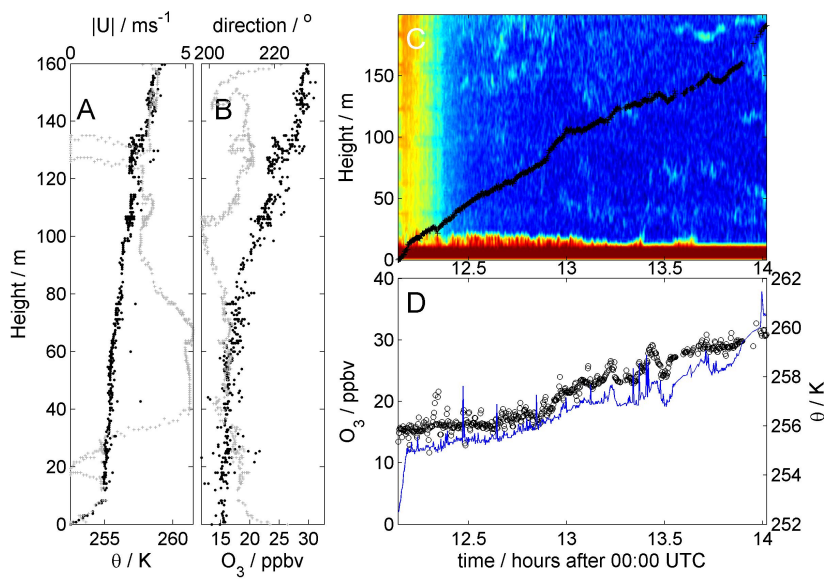

Fig. 4. As for Fig. 3, but for 24 August 2007. Please note the difference in scales.

show a clear layer of increased backscatter, indicating enhanced turbulence within this region. This layer is either being generated in situ by wind shear, or is a remnant of past shear action (fossil turbulence, see Culf, 1989); for this event, the wind profile data are not of sufficient quality to address this uncertainty. Above $100 \mathrm{~m}$, ozone mixing ratios reached, and remained at background amounts of roughly $30 \mathrm{ppbv}$ to the top of the flight track at $200 \mathrm{~m}$. On the descent flight, the $\sim 100 \mathrm{~m}$ turbulent layer was still evident in the sodar echogramme (Fig. 5c) and, according to the sharp discontinuity in ozone (Fig. 5a and d), was acting as a significant barrier to mixing.

We interpret these data as indicating three main air masses, with different histories that had been retained. Interestingly, in this example, a correlation between ozone and potential temperature is maintained in the lowest layer of the atmosphere.

\subsubsection{Profile experiment 2 September 2007 - daytime flight}

The first flight on 2nd September was carried out midafternoon during the onset of an ODE. It revealed a series of layers in the atmosphere between the ground and the upper reaches of the sonde (see Fig. 6). The lowest was, once again, a well-defined and very shallow layer, reaching only $\sim 15 \mathrm{~m}$ above the ground (Fig. $6 \mathrm{a}$ and b). Higher up were two clearly-defined air masses that contained wellmixed ozone, i.e. with little or no vertical gradient. The first spanned the region between $\sim 60 \mathrm{~m}$ and $180 \mathrm{~m}$, and was characterised by ozone mixing ratios of $\sim 20 \mathrm{ppbv}$ and small potential temperature gradient $\left(<0.01 \mathrm{Km}^{-1}\right)$, i.e. neutrally stratified. The second extended above $250 \mathrm{~m}$ to the top of the profile $(\sim 370 \mathrm{~m})$, with ozone mixing ratios of $\sim 28 \mathrm{ppbv}$ and $\partial \theta / \partial z=0.02 \mathrm{Km}^{-1}$. A region of mixing, with a clear gradient in both $\mathrm{O}_{3}$ and $\theta$, lay between $180 \mathrm{~m}$ and $250 \mathrm{~m}$.

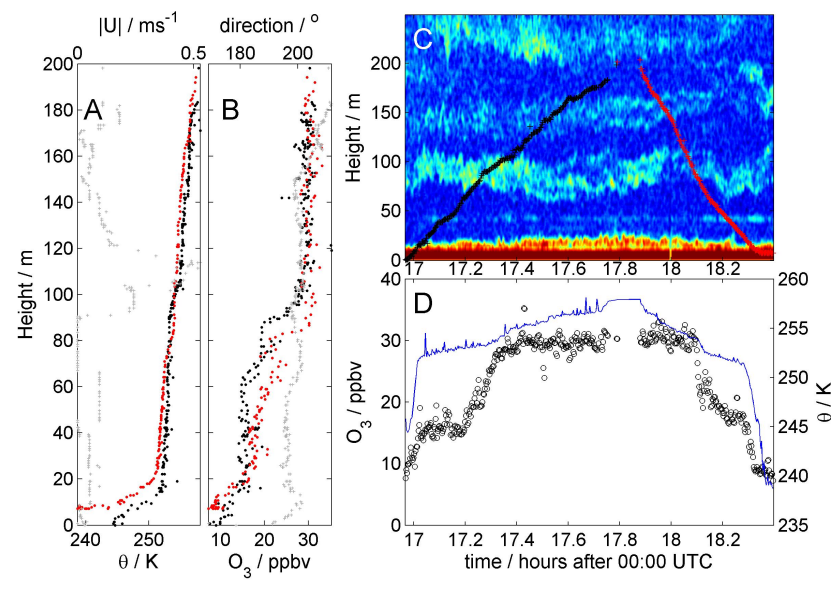

Fig. 5. As for Fig. 3, but now for 25 August 2007. Please note the difference in scales.

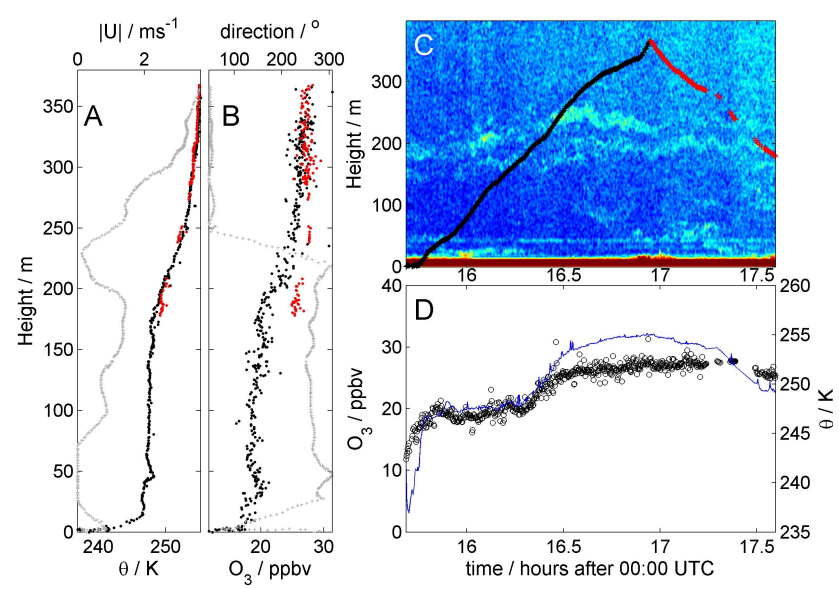

Fig. 6. As for Fig. 3, but for the first flight on 2 September 2007. Please note the difference in scales.

The surface winds on this occasion were light, $\sim 2 \mathrm{~ms}^{-1}$, but the profile of wind speed, and more significantly, wind direction (not shown) reveals that the two air masses were quite distinct. In the lower region, the air originated from the $270^{\circ} \pm 20^{\circ}$ sector (West), while in the upper region, the air mass originated from $55^{\circ} \pm 10^{\circ}$ sector (North East). Within the transition region, the winds drop to zero, and backs via North. In the lower region there is a local maximum in wind speed, (from near zero at the surface, and zero again in the transition region). Given the neutral stratification, the wind shear in this region should produce a well mixed air mass. In the upper region, the winds increase monotonically throughout, with $\partial U / \partial z=0.033 \mathrm{~s}^{-1}$. This gives $R i=0.7$, implying very weak mixing.

The sodar data show two associated echo layers within the transition region, and we interpret these as the upper and lower limits of the shear region, where the air masses are sliding over each other. The clear difference in wind direction 

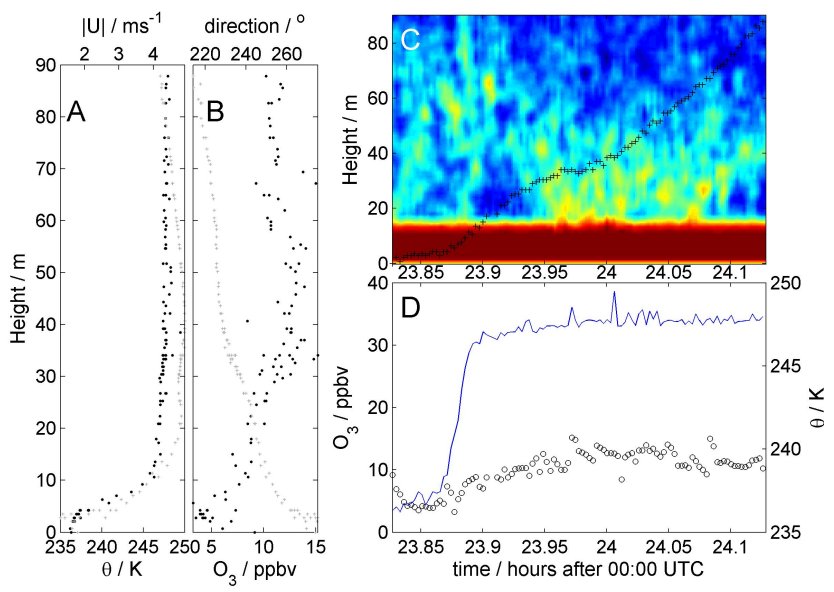

Fig. 7. As for Fig. 3 but now for the night-time flight spanning $2 / 3$ September 2007. Please note the difference in scales.

implies a different history for the air masses, the lower being recently advected over the ocean, the upper being continental air (King, 1989, 1993).

\subsubsection{Profile experiment 2 September 2007 - night-time flight}

A second flight was carried out late on 2nd September which was only able to measure to $85 \mathrm{~m}$ altitude. Above this height, the battery failed, probably because of the lower temperatures. It was dark during this flight, and, according to the surface ozone measurements (Fig. 2a), the ODE was in its recovery stage. Figure 7 a shows that the lowest atmospheric layer was extremely shallow, extending to less than $10 \mathrm{~m}$ above the ground, but that, again, this structure was not reflected in the ozone profile (Fig. 7b). During the dark, ozonedepletion chemistry would not be active, so a strong correlation between $\theta$ and $\mathrm{O}_{3}$ would not necessarily be expected.

\subsubsection{Profile experiment 7 September 2007}

The final tethersonde flight of this campaign was carried out on 7 September during daylight hours (Fig. 8). According to the surface ozone data (Fig. 2a), the air measured at Halley was only partially depleted, and the sonde was launched close to the maximum depletion observed. Battery voltage was good to $\sim 140 \mathrm{~m}$ on the ascent flight.

The flight shows three distinct atmospheric layers. A strong positive potential temperature gradient extends from the surface to $\sim 20 \mathrm{~m}$ indicating highly stratified air (Fig. $8 \mathrm{a}$ ). This structure is not matched by structure in the ozone profile (Fig. 8b). These data suggest an air mass whose potential temperature structure is still evolving en route to Halley, while ozone has not changed. Between $20 \mathrm{~m}$ and $100 \mathrm{~m}$, the potential temperature gradient is much weaker, but nonetheless positive and therefore stratified. No significant change
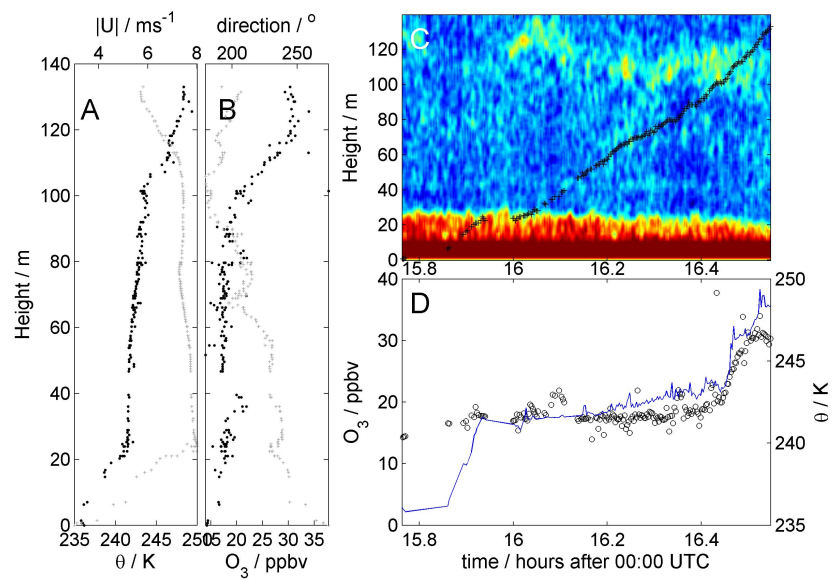

Fig. 8. As for Fig. 3 but now for the flight of 7 September 2007. Please note the difference in scales.

in ozone is measured over this distance. However, between $100 \mathrm{~m}$ and $120 \mathrm{~m}$, there is a transition zone with clear discontinuities in both ozone and potential temperature. Above $\sim 120 \mathrm{~m}$, ozone mixing ratios return to background amounts ( $\sim 30 \mathrm{ppbv})$.

The sodar (Fig. 8c) shows associated echo return within the lowest $20 \mathrm{~m}$, and again within the transition zone around $100 \mathrm{~m}$ altitude. Thus far, the event is similar to that of the first flight on the 2nd of September (above), except in the amount of ozone depletion near the ground. Further similarity is observed in the winds, where, although not reversing in direction, the easterly component of the wind increases with height by $2 \mathrm{~ms}^{-1}$ within the transition zone, implying again maritime air advected underneath continental air. Further evidence is apparent in the sodar data, where fossil convection is quite plain within the $20 \mathrm{~m}$ to $100 \mathrm{~m}$ depleted zone, suggesting that the air has recently traversed a polynya, with associated convection (Anderson, 1993; Culf, 1989).

\subsubsection{Tethersonde study: implications}

This was the first concentrated assessment of the detailed vertical structure of a number of ozone depletion events. The overall technique used to study ODEs, using tethersonde launches triggered by surface ozone data, worked well, with a number of ODEs probed and under a variety of stages of depletion. The tethersonde was able to probe the lowest few hundred meters in considerably greater detail than could be achieved using a free-flying sonde.

The tethersonde study revealed the enormous complexity within the lowest layers of the atmosphere and the influence exerted by atmospheric structure and dynamics on observed ozone profiles. The observations suggest that numerical modelling studies aimed at reproducing ODEs observed at coastal sites will need to account in some detail for the influence of atmospheric dynamics on ozone mixing ratios. 
Such data would then provide excellent constraints against which to test ideas on local ozone depletion processes. It is also clear that the lowest atmospheric layer at Halley can be extremely shallow at times, something that is more closely associated with sites on the Antarctic plateau.

The data, further, highlight the difficulty in defining a relevant boundary layer height. This issue is important, for example, when translating a measured surface flux into a boundary layer concentration, and also when deriving a mixing ratio from a slant or vertical column density. Assessment of mixing height would therefore seem a welcome companion to many chemical measurement programmes. Further, considerable variability can exist in the profile of ozone, and it appears that concentrations can be influenced by several physical layers at different heights. For example, a significantly lower mixing height can be rapidly established as air moves from over the convective sea ice zone (mixing height of the order $100 \mathrm{~m}$ ) to over the stably stratified ice shelf (mixing height $\sim 20 \mathrm{~m}$ ). We note also that the relationship between ozone and potential temperature $(\theta)$ can be very subtle, and that correlations do not always exist between these parameters - especially near the ground.

Finally, as the blimp profiling system cannot be deployed under windy conditions, the low altitude profiles reported here are, by definition, all relatively low wind speed events $\left(\sim 1 \mathrm{~ms}^{-1}\right.$ to $\left.\sim 7 \mathrm{~ms}^{-1}\right)$. Low wind speed ODEs are often associated with local depletion (e.g. Simpson et al., 2007), and indeed two local ODEs previously studied at Halley were measured at wind speeds between zero and $\sim 5 \mathrm{~ms}^{-1}$ (Jones et al., 2006). The majority of the tethersonde profiles reported here appear to arise from local processing under quiescent conditions, and it is interesting to note that the ozone depletion is restricted to the lowest $10 \mathrm{~s}$ to $\sim 100 \mathrm{~m}$ altitude. Maps of $\mathrm{BrO}$ measured by the satellite-borne SCIAMACHY (SCanning Imaging Absorption SpectroMeter for Atmospheric CHartographY) instrument (Richter et al., 1998; Bovensmann et al., 1999) (not shown), indicate no major increases in the $\mathrm{BrO}$ column in the Halley region during the ODEs measured by the tethersonde. This may be linked to the low sun at the time of satellite overpass over Halley at this time of the year but alternatively may imply that on these occasions the local production of bromine compounds was not sufficient to significantly enhance the $\mathrm{BrO}$ column. In terms of export of halogens or of air low in ozone that might affect the radiative balance of the atmosphere, it therefore appears that low wind speed ODEs, driven by local processing, have few wider atmospheric implications. Their merit, however, lies in their providing excellent cases against which to test kinetics and chemical mechanisms involved in depleting polar tropospheric ozone.

\subsection{The 1987 free-flying ozonesonde study}

\subsubsection{Time-series of ozone profiles}

Data from the free-flying ozonesonde study show considerably less fine-scale detail than the tethersonde profiles described above, but enable a much broader view to be gained of ozone behaviour throughout the troposphere. Figure 9 is a contour plot derived using measurements from all the ozonesonde launches between 26 July 1987 and 14 November 1987. The dots represent the individual data points and hence show the data coverage, the degree of smoothing in the diagram and the days when no sonde launches were made. The lack of at least daily data coverage becomes problematic later, when trying to understand mechanisms driving high altitude ozone depletion by linking with meteorological information available at 6-hourly resolution. The reason for the lack of sonde launch varies - sometimes due to the planned schedule, but sometimes due to high wind speeds, a fact which becomes relevant later.

There are various features in Fig. 9 that are immediately obvious. Firstly, the data coverage varies quite considerably during this period shown. For example, from 2 August to 6 September, sondes were launched every day. In contrast, from 7 September to 15 September there were only 3 sonde launches. Also obvious are the ODEs, indicated by the blues of the false colour scale, which were measured between 22 August and 7 October. The vertical extent of the ODEs varies considerably. There are various occasions when depletion extends only to a few hundred meters above the ground (e.g. 25/26 August and 7 October). However, there are also profiles showing ozone depletion to several kilometres altitude, to a maximum of $\sim 3.5 \mathrm{~km}$ on both 29 September and $3 \mathrm{Oc}$ tober. Of note also are two dislocated events, where ozone at ground level shows unperturbed background concentrations, but by an altitude of roughly $200 \mathrm{~m}$, significant depletion is apparent. Such ODEs are, by definition, unattainable by surface measurements, and are an example that the groundbased record does not reveal the complete picture regarding ODEs. Studies aimed at addressing trends in ODEs would need to take that into account.

The data thus hold significant amounts of information, but, as the record is somewhat limited by periods when no sondes were launched, they must be interpreted with care. For example, a severe ODE is evident on 22 August with less extensive depletion apparent on 25 and 26 August. However, as there were no sonde launches on 21, 23 or 24 August, and with the lack of surface $\mathrm{O}_{3}$ observations in 1987, it is not possible to say when this event started or whether this was a single long event or two shorter ones. The sonde data must be viewed as a series of snapshots.

They can nevertheless considerably extend our understanding of ODEs that occur at Halley. For example, a key question that can be addressed with these data is: what drives ODEs to such remarkable altitudes? Given that the depletion 


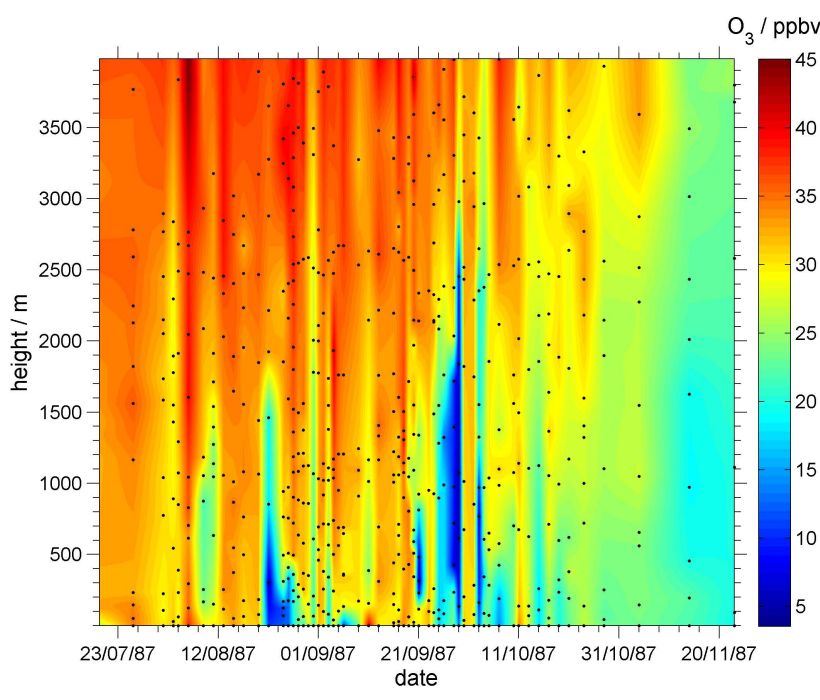

Fig. 9. Contour plot showing the vertical profile of tropospheric ozone against time derived from balloon-borne ozonesonde ascents during austral spring 1987. Tick marks are at 00:00 GMT every 4 days. Each dot indicates a measurement point; the irregular vertical grid is apparent, but so is the relatively good data coverage of ODEs.

of ozone is caused by a source associated with sea ice, i.e. initially ground-based, how can the signature of depletion attain heights to several kilometres above the ground? We explore this issue in the rest of this paper, focussing on events where ozone depletion was evident in the profile up to and above $1 \mathrm{~km}$ altitude. We initially consider the air mass origin of dislocated events using 5-day back trajectories. We then consider profiles where depletion is continuous upwards from ground level, and the regional meteorological situation around the time of the profile measurements.

\subsubsection{Origin of the dislocated events}

Back trajectories were calculated for both of the dislocated events using the on-line trajectory model of the British Atmospheric Data Centre (fully described at http://badc.nerc. ac.uk/community/trajectory/). The trajectories were calculated using meteorological fields from the ECMWF at a resolution of $2.5^{\circ}$, the maximum available for this time period, and were run backwards from Halley for 5 days. In each case trajectories ending at different pressure levels were calculated in order to provide information on the history of air mass at different heights in the ozone profile.

Figure 10a and $\mathrm{b}$ show the histories of air arriving over Halley on 21 and 28 September. On each occasion, air at ground level shows unperturbed concentrations of ozone while those at altitude show significant depletion. The back trajectories show that in both cases, air arriving close to ground level (980 and $950 \mathrm{hPa}$ ) had originated over the cold continent to the east of Halley. Air arriving at higher altitudes, shown by the sonde data to be depleted in ozone, had
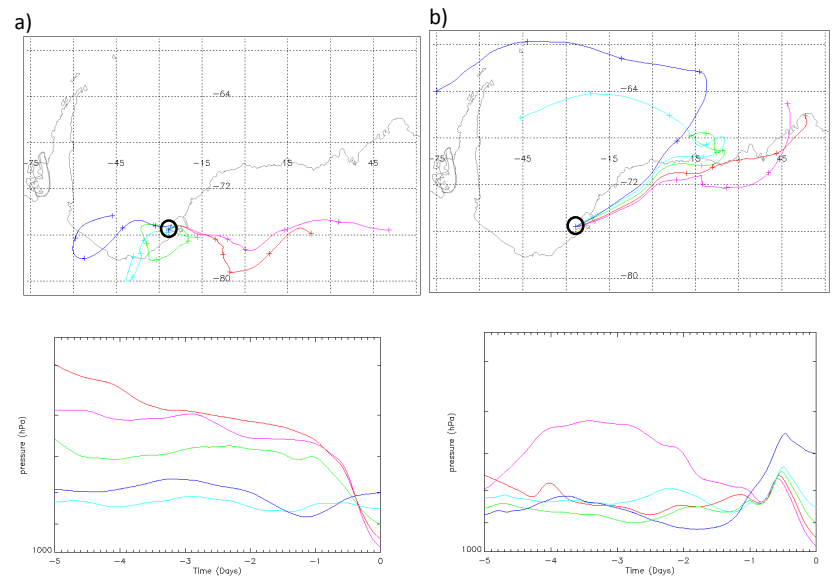

Fig. 10. 5-day back trajectories showing the contrasting origin of air arriving at different altitudes at Halley. (a) 21 September 1987: the pink and red trajectories correspond to air arriving at 980 and $950 \mathrm{hPa}$ respectively; the green, turquoise, and blue lines are the trajectories for air parcels arriving at Halley at 900, 850 and $800 \mathrm{hPa}$ respectively (i.e. between $\sim 1 \mathrm{~km}$ and $\sim 2 \mathrm{~km}$ above ground level the altitude region of low ozone air in the profile on this day). (b) 28 September 1987: the pink and red trajectories correspond to air arriving at 980 and $950 \mathrm{hPa}$ respectively; the green, turquoise, and blue lines are the trajectories for air parcels arriving at Halley at 900, 850 and $700 \mathrm{hPa}$ respectively (i.e. between $\sim 1 \mathrm{~km}$ and $\sim 3 \mathrm{~km}$ above ground level - the altitude region of low ozone air in the profile on this day). Halley is marked by the black circle on the plot; trajectory markers are at $24 \mathrm{~h}$ intervals.

tracked over the sea ice zone. On 21 September the route was over the frozen southern Weddell Sea with an approach to Halley from the south west. On 28 September, air had originated much further north, tracked the coastal fringes of the sea ice zone and finally arrived at Halley from a north easterly direction. The maritime origin is confirmed by data from radiosonde launches carried out separately but on the same day. The humidity profile in the radiosonde data (not shown) reveals, in both cases, an increase in moisture in the ozone-depleted layer. The fact that the profile at Halley was dislocated thus appears to be driven simply by different largescale air mass origins. This conclusion is in line with observations reported by Wessel et al. (1998) where an ozonesonde launched at Neumayer station $\left(8^{\circ} \mathrm{W}, 70^{\circ} \mathrm{S}\right)$ revealed air with limited ozone depletion at ground level that was overlain by a highly depleted air mass. Wessel et al. explained their observation as cold katabatic surface winds, originating over the continental ice shelf, lifting up warmer and less dense marine air masses that had lower ozone mixing ratios. We return to this later.

\subsubsection{The broader picture}

To further explore the drivers of high altitude ODEs we consider charts of mean sea level pressure (mslp), together with 


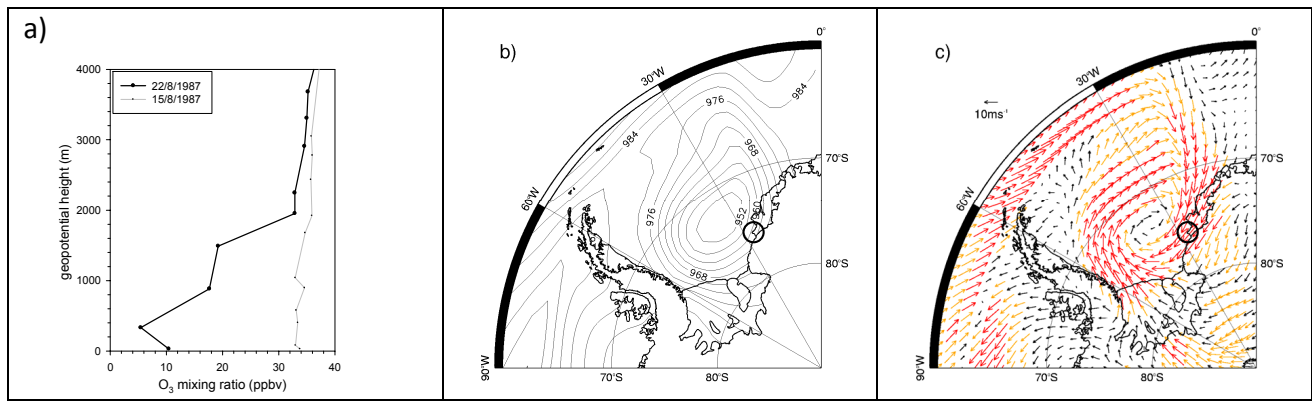

Fig. 11. (a) Ozonesonde measurements on 22 August 1987 compared with an un-depleted profile for the middle of the same month; (b) mean sea level pressure on 21 August 1987 (noon); (c) 10-m wind vectors on 21 August 1987 (noon) - wind speeds identified as: black =< $8 \mathrm{~ms}^{-1}$; orange $=8$ to $12 \mathrm{~ms}^{-1}$; red $=>12 \mathrm{~ms}^{-1}$. Halley is marked by the black circle on the plots.

10-m wind vectors (which indicate the speed and direction of winds at $10 \mathrm{~m}$ above the ground), to gauge the regional meteorological situation around the time of the observed ODEs. We utilise the European Centre for Medium Range Weather Forecasts (ECMWF) 40-year reanalysis (ERA-40), which is described in Uppala et al. (2005). The reanalysis has been retrieved on a Gaussian N80 grid, with a grid cell spacing of $\sim 125 \mathrm{~km}$.

In the relevant plots the 10-m wind speed vectors are classified by a series of colours according to their speed. The thresholds were chosen according to a study on an Antarctic ice shelf (Mann et al., 2000) which concluded that when the $10-\mathrm{m}$ wind speed reached between $8 \mathrm{~ms}^{-1}$ and $12 \mathrm{~ms}^{-1}$ (shown in amber on the plots) particles of snow or ice were dislodged from the snow surface and bounced into a $\sim 10 \mathrm{~cm}$ deep "saltation layer". At 10-m wind speeds in excess of $12 \mathrm{~ms}^{-1}$ (shown in red on the plots) particles were lofted out of the saltation layer and formed what is classically referred to as blowing snow. ERA-40 wind vectors are likely to give a good indication of wind speed, and therefore reflect whether snow was lofted or blowing.

Figure 11a shows the profile of ozone as measured using the free-flying balloon-sonde on 22 August 1987. The figure also shows an un-depleted profile from the middle of the same month. The degree of ozone depletion is clear, extending from ground level to $\sim 2000 \mathrm{~m}$ altitude. Figure 11b) shows the mslp chart for the preceding day, 21 August 1987, with a huge low pressure system situated off-shore of Halley and encompassing the majority of the Weddell Sea area. The 10-m wind vectors on 21 August 1987 are shown in Fig. 11c) and their colouring shows that over large areas, snow/ice will be lofted either into a saltation layer or higher into the atmosphere as blowing snow. Unfortunately no sonde was launched from Halley on 21 August 1987 precisely because of the high winds. By 22 August 1987, ERA-40 charts show that the depression is still present over the Weddell Sea, but that it is much less intense than on the 21st.

Figure 12a shows the ozone profile on 21 September 1987, the first dislocated event for which we calculated trajectories, above. Again a typical un-depleted profile from the middle of the month is also shown, and it is clear that on 21 September 1987, ozone is depleted to $\sim 2000 \mathrm{~m}$, but with the largest bite from the profile extending from $\sim 200 \mathrm{~m}$ to $\sim 1000 \mathrm{~m}$. The back trajectories in Fig. 10a show that the air originating within the most depleted layer arrived at Halley from over the southern Weddell Sea. Figure 12b shows the mslp on this day, and the presence of a large, moderately deep low pressure system over the Weddell Sea. Figure 12c shows that the wind speeds at $10-\mathrm{m}$ maximise in the $8 \mathrm{~ms}^{-1}$ to $12 \mathrm{~ms}^{-1}$ range, suggesting that snow and ice would be lofted into a saltation layer. The air, shown by the back trajectory analysis to arrive at altitudes over Halley of between 900 and $800 \mathrm{hPa}$, with its route across the southern Weddell Sea, is thus highly likely to have been impacted by the depression. The following day the winds were too high to launch a sonde, so we have no information on whether depletion was sustained.

The ozonesonde launched on 24 September 1987 shows small but limited amounts of depletion in the ozone profile (not shown). That launched on 25 September 1987, in contrast, shows clear and significant depletion in the ozone profile to over $2000 \mathrm{~m}$ altitude (see Fig. 13a). From the mean sea level plot of the 24 September 1987 (Fig. 13b), a significant low pressure system was situated offshore of Halley on this day. The associated winds (Fig. 13c) are just below the $12 \mathrm{~ms}^{-1}$ threshold in the vicinity of Halley, and above $12 \mathrm{~ms}^{-1}$ on the western side of the Weddell Sea. Thus, the atmosphere on the day prior to the depleted profile measurement was significantly impacted by the storm, but no response was evident at that time in the Halley profile. On 25 September 1987, it is clear from the ERA-40 data (not shown) that the depression, although still present, was considerably weaker than on the 24th. By the 26 September 1987 , although depletion is still evident in the ozone profile (Fig. 14a), the centre of the depression had shifted northwards (Fig. 14b) and the wind speeds across the Weddell Sea had eased considerably (Fig. 14c). It is likely that the depletion evident on the 26th was a remnant of earlier ozone destruction. 


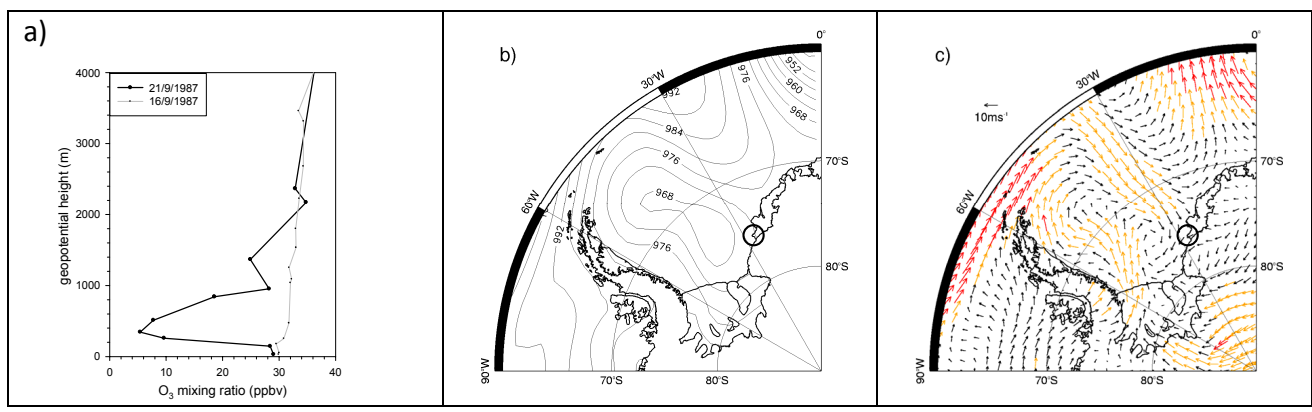

Fig. 12. (a) Ozonesonde measurements on 21 September 1987 compared with an un-depleted profile for the middle of the same month; (b) mean sea level pressure on 21 September 1987 (noon); (c) 10-m wind vectors on 21 September 1987 (noon) - wind speeds identified as: black $=<8 \mathrm{~ms}^{-1}$; orange $=8$ to $12 \mathrm{~ms}^{-1}$; red => $12 \mathrm{~ms}^{-1}$. Halley is marked by the black circle on the plots.

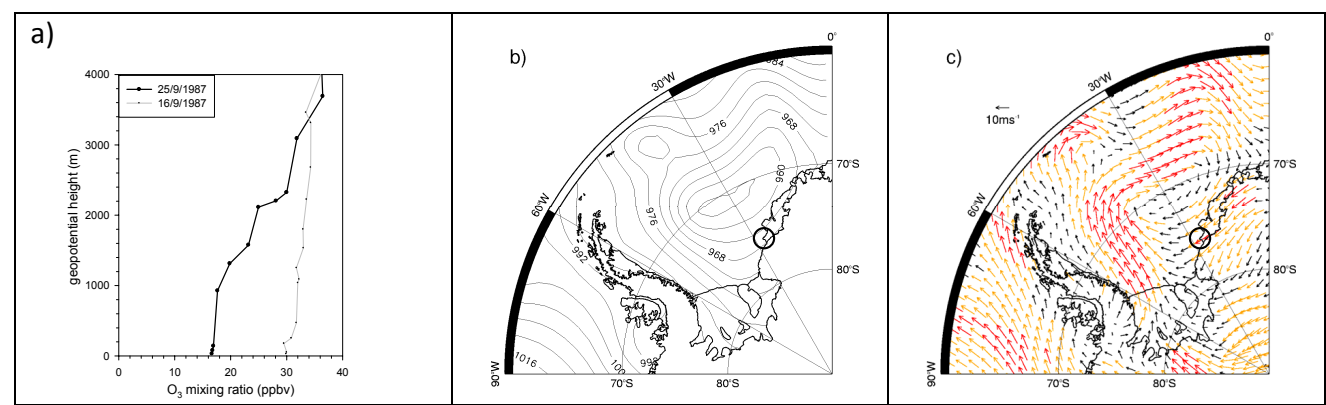

Fig. 13. (a) Ozonesonde measurements on 25 September 1987 compared with an un-depleted profile for the middle of the same month; (b) mean sea level pressure on 24 September 1987 (noon); (c) 10-m wind vectors on 24 September 1987 (noon) - wind speeds identified as: black $=<8 \mathrm{~ms}^{-1}$; orange $=8$ to $12 \mathrm{~ms}^{-1} ;$ red $=>12 \mathrm{~ms}^{-1}$. Halley is marked by the black circle on the plots.

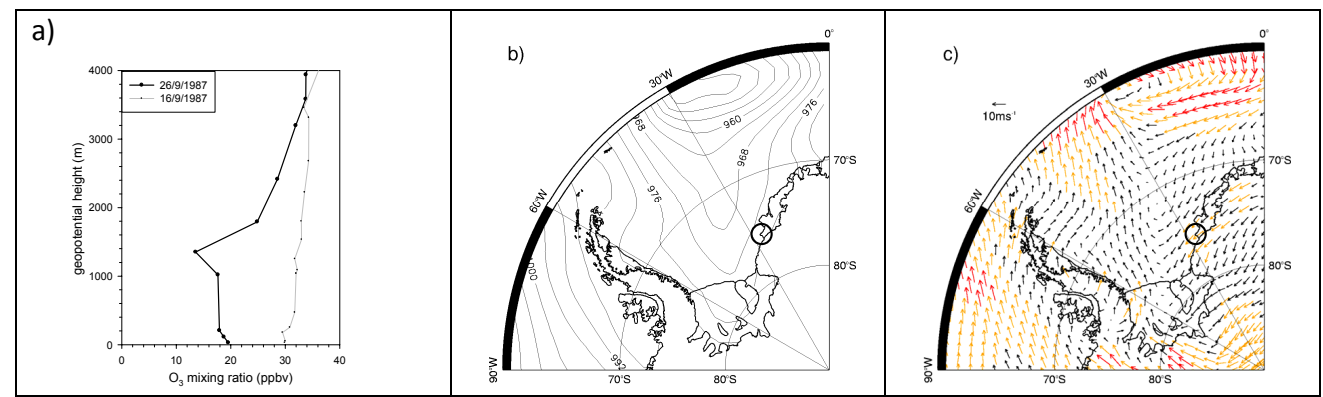

Fig. 14. (a) Ozonesonde measurements on 26 September 1987 compared with an un-depleted profile for the middle of the same month; (b) mean sea level pressure on 26 September 1987 (noon); (c) 10-m wind vectors on 26 September 1987 (noon) - wind speeds identified as: black $=<8 \mathrm{~ms}^{-1}$; orange $=8$ to $12 \mathrm{~ms}^{-1} ;$ red $=>12 \mathrm{~ms}^{-1}$. Halley is marked by the black circle on the plots.

Figure 15a shows the ozone profile measured on 28 September, the second dislocated event described above. The back trajectory calculation (Fig. 10b) shows that air in the layer between 900 and $700 \mathrm{hPa}(\sim 3000 \mathrm{~m})$ had passed over the sea ice zone to the north west of Halley before arriving over the base. The mean sea level plot for 27 September 1987 (Fig. 15b) shows that a large low pressure system was present in this area on the day before the depleted profile was mea- sured at Halley. The 10-m wind speed vectors suggest that the depression resulted in considerable amounts of blowing or saltating snow in the atmosphere (Fig. 15c). Similar to the event described above, mslp and 10-m wind vector charts (not shown) indicate that on 28 September, the low was still present although weaker, but with wind speeds still sufficient to cause suspended snow. By 29 September, the depression influencing Halley had completely dissipated (Fig. 16b) such 


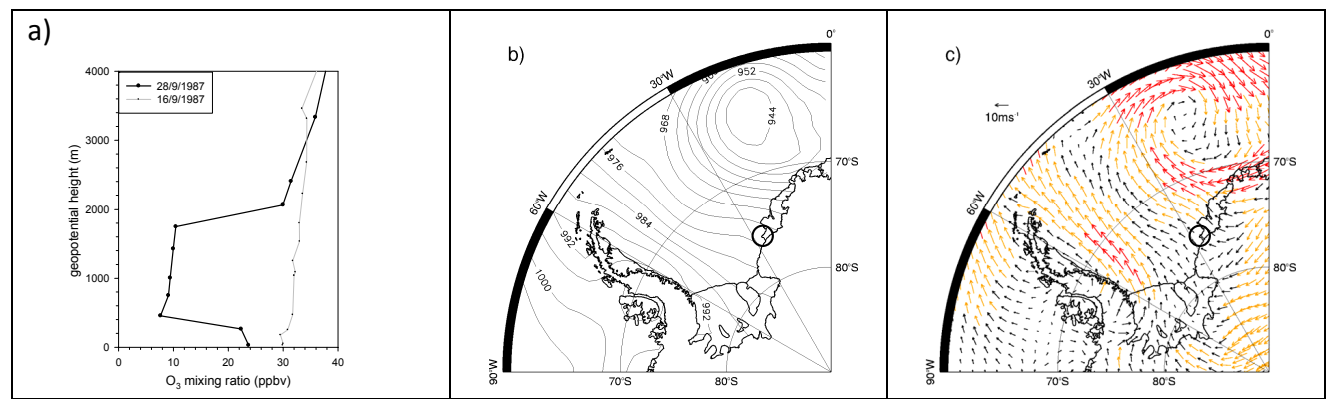

Fig. 15. (a) Ozonesonde measurements on 28 September 1987 compared with an un-depleted profile for the middle of the same month; (b) mean sea level pressure on 27 September 1987 (noon); (c) 10-m wind vectors on 27 September 1987 (noon) - wind speeds identified as: black $=<8 \mathrm{~ms}^{-1} ;$ orange $=8$ to $12 \mathrm{~ms}^{-1} ; \operatorname{red}=>12 \mathrm{~ms}^{-1}$. Halley is marked by the black circle on the plots.

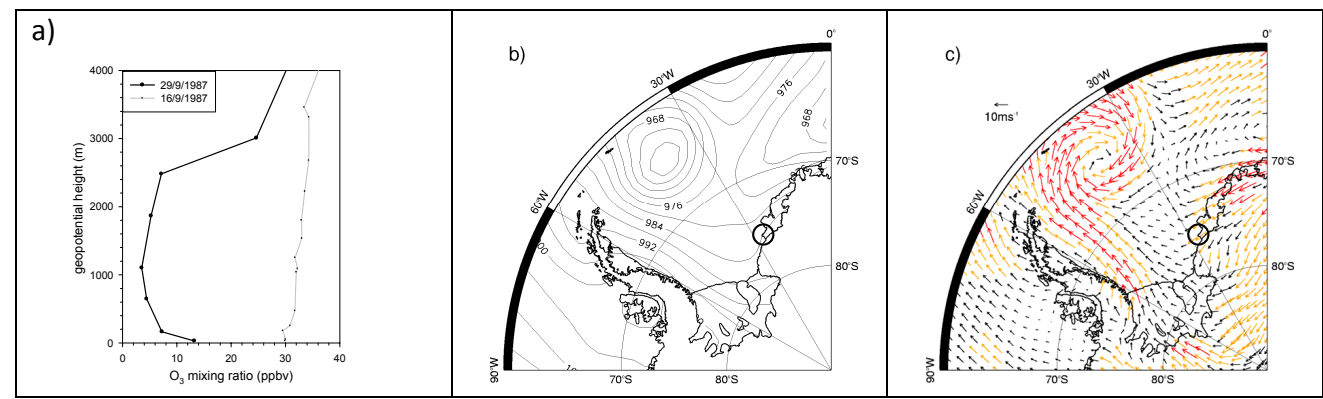

Fig. 16. (a) Ozonesonde measurements on 29 September 1987 compared with an un-depleted profile for the middle of the same month; (b) mean sea level pressure on 29 September 1987 (noon); (c) 10-m wind vectors on 29 September 1987 (noon) - wind speeds identified as: black $=<8 \mathrm{~ms}^{-1}$; orange $=8$ to $12 \mathrm{~ms}^{-1}$; red $=>12 \mathrm{~ms}^{-1}$. Halley is marked by the black circle on the plots.

that the winds in the vicinity of Halley had eased (Fig. 16c) a new low pressure system had formed in the western Weddell Sea area but with no influence on air masses at Halley at that time. The ozonesonde released at Halley on 29 September shows that ozone depletion extended from the surface to well over $3000 \mathrm{~m}$ altitude (Fig. 16a) most likely a remnant of processing over the previous days.

The final sonde launch of 1987 that showed ozone depletion at considerable altitudes was that of 3 October. The sonde was launched around 1600, and Fig. 17a) shows that depletion was evident from the surface to $\sim 2500 \mathrm{~m}$, with a maximum around $800 \mathrm{~m}$ altitude. ERA- 40 mslp charts over the preceding time period show that a low pressure system was present over the Weddell Sea on 3 October which was at its most intense at 0600 , i.e. $10 \mathrm{~h}$ before the sonde launch (see Fig. 17b). The associated 10-m wind vectors (Fig. 17c) suggest that the atmosphere would have been influenced by lofted and blowing snow in the Halley region around 06:00. No significant depletion is evident in the ozonesonde launch of 2 October. These data help to provide some time constraints for ozone processing and suggest that significant depletion can occur within $10 \mathrm{~h}$ of the low pressure maximum.

\subsubsection{Free-flying ozonesonde study at Halley: conclusions}

In a recent paper we derived a relationship describing the likelihood of ODEs based upon wind speed (see Jones et al., 2009, Fig. 12d). The pre-requisite of low wind speeds and a stable boundary layer has been described by a number of authors (e.g. Jacobi et al., 2006; Jones et al., 2006; Simpson et al., 2007). In addition, Jones et al. (2009) demonstrated that ODEs can develop under conditions of high winds and blowing snow. The conclusion was arrived at from a detailed case study around Halley and the Weddell Sea in which an active ODE appeared to be generated during an intense Antarctic storm. Ground-based measurements at Halley showed that during the storm, saline blowing snow was lofted into the atmosphere. Concurrent satellite data revealed an extensive region of enhanced $\mathrm{BrO}$ across the Weddell Sea. These observations added considerable support to two 3-D modelling studies of Yang et al. $(2008,2010)$ which suggested that blowing snow events over sea ice could be a major source of sea salt aerosol, and that this aerosol could in turn generate bromine that would destroy tropospheric ozone. No information about the vertical profile of ozone was available for the Halley case study. 


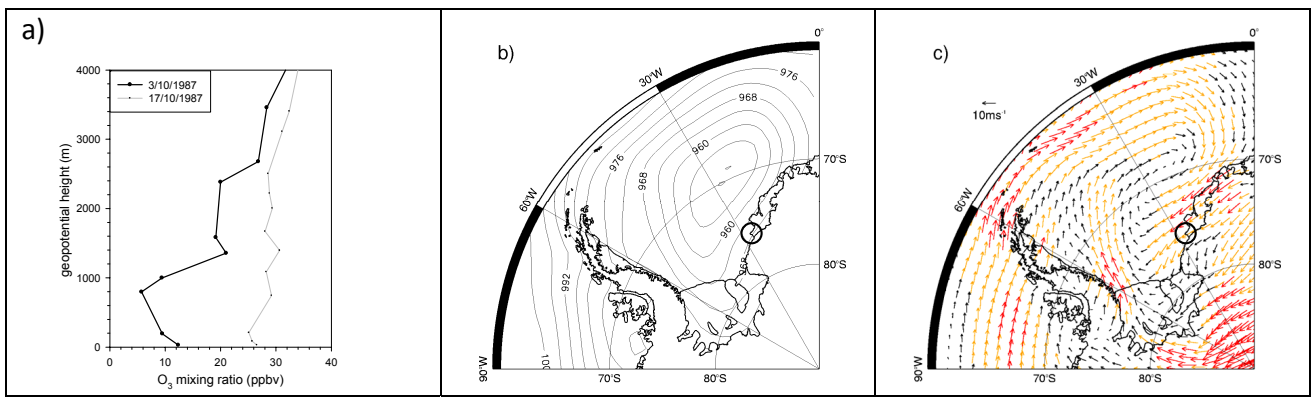

Fig. 17. (a) Ozonesonde measurements on 3 October 1987 compared with an un-depleted profile for the middle of the same month; (b) mean sea level pressure on 3 October 1987 (06:00); (c) 10-m wind vectors on 3 October 1987 (06:00) - wind speeds identified as: black =< $8 \mathrm{~ms}^{-1}$; orange $=8$ to $12 \mathrm{~ms}^{-1}$; red $=>12 \mathrm{~ms}^{-1}$. Halley is marked by the black circle on the plots.

Windy conditions in themselves are of course not sufficient to drive ozone depletion, and the 1987 observations clearly demonstrate this point. For example, on 24 September 1987, a large and vigorous low pressure system was operative across the Weddell Sea, with lofted and blowing snow likely present in the region of Halley. However, the ozone profile measured at Halley on this day did not reveal significant ozone depletion. An interesting feature revealed by the ERA-40 surface temperature charts is that temperatures across the Weddell Sea were significantly higher on 24 September than on the following day when ozone depletion was observed to over $2 \mathrm{~km}$. Further, ODEs observed under conditions of high wind speeds can arise from transport to the observation site of air masses already depleted in ozone (e.g. Simpson et al., 2007). Thus separating out the role of low pressure systems, into chemically driving depletion as opposed to transporting already-depleted air masses, is no simple task.

So, windy conditions are not a sufficient, but are a necessary condition. It is clear from the data presented here that all the 1987 events with high altitude ozone loss were associated with significant atmospheric depressions, windy conditions, and lofted or blowing snow. In each case, the low pressure system preceded the measurement of the depleted profile, but unfortunately the temporal resolution of the data is too limited to allow a clear statement on the timescales involved in processing and depletion which might be used to test/confirm the mechanisms proposed by Yang et al. $(2008,2010)$.

\section{Discussion}

\subsection{Re-visiting earlier published studies}

Although the analyses from 1987 Halley are very consistent, these are a limited number of events measured at a single location. In order to expand our dataset, we consider here published ozone soundings made at other Antarctic stations that also show high altitude ozone loss. To gain the broader picture, we again turn to ECMWF re-analyses. For the pe- riod up to 2001 we utilise the ERA-40 reanalysis (described earlier), and for more recent data we analyse the ECMWF Interim Reanalysis, which starts in 1989 and is updated to the present time. The latter has also been retrieved on a Gaussian N80 grid, with a grid cell spacing of $\sim 125 \mathrm{~km}$.

Wessel et al. (1998) focussed on dynamical processes occuring during ODEs observed at Neumayer station in austral spring 1993. They highlighted three dislocated events, the most intense featuring depletion to $\sim 3000 \mathrm{~m}$ altitude. From back-trajectory calculations, they concluded that the dislocation arose because air low in ozone, with a source over the sunlit sea ice, was uplifted over continental air. They further noted that the ozone-depleted air was transported to Neumayer by marine cyclones that developed over the icecovered South Atlantic Ocean. Although the discussion was in terms of transport, rather than as a key player in the depletion process, a clear link was nonetheless made between high altitude ODEs and low pressure systems.

A paper by Kreher et al. (1997) presents a number of ozone profiles, and extends the picture by including halogen data. They describe measurements of $\mathrm{BrO}$ made in austral spring 1995 at Arrival Heights, part of the New Zealand station on the edge of the Ross Sea $\left(77.8^{\circ} \mathrm{S}, 166.7^{\circ} \mathrm{E}\right)$. The observations were made with a zenith sky DOAS (Differential Optical Absorption Spectrometer) at high solar zenith angle ( $86^{\circ}$ and $90^{\circ}$ ) - i.e. twilight dawn and dusk. In particular, they focus on two events with enhancement in tropospheric $\mathrm{BrO}$, the first from dusk on 24 to dusk on 26 August and the second from dusk on 15 to dusk on 16 September. The authors link their $\mathrm{BrO}$ data with ozonesonde measurements made at the nearby McMurdo station on 25 August and 15 September, which show depletion in the profile to several kilometres altitude. We studied the ERA-40 meteorological charts for that region and time period, and found that on 23 August, the day before enhanced $\mathrm{BrO}$ was observed, a low pressure system was situated in the area which by noon was over the Ross Sea. By 18:00, its position was such that, as well as enhancing katabatics descending from the Antarctic Plateau, it was drawing air from the sea ice zone to Arrival Heights (see 
Fig. 18a). Wind speeds were sufficiently high to cause saltation and blowing snow (Fig. 18a). The storm lasted through the night but ERA-40 charts show that it eased over the following day, such that by 18:00 on 24th, 10-m wind speeds around Arrival Heights were below the threshold for lofted snow. A similar situation arose around the time of the second enhanced $\mathrm{BrO}$ event. An atmospheric depression, centred over the boundary between the Ross Ice Shelf and the Ross Sea on 14 September resulted in high wind speeds in the region around Arrival Heights and generally high winds across the whole area (Fig. 18b). By the following day, when the $\mathrm{BrO}$ enhancement was first measured, the low had moved to the western side of the Ross Sea and winds around Arrival Heights were dominated by katabatic flow, although still high enough for saltation (not shown).

A subsequent paper by Roscoe et al. (2001) used the results of Kreher et al. (1997) and expanded them to include some additional data from Neumayer. Specifically, the authors considered zenith sky DOAS and ozonesonde measurements from Neumayer that showed enhanced tropospheric BrO on 2 August 1995 that coincided with an ozone profile that was severely depleted to $\sim 3 \mathrm{~km}$ altitude. ERA-40 charts show that on 1 August 1995, a moderate depression was situated offshore of Neumayer, with winds in the coastal region above the threshold for saltating and blowing snow (see Fig. 18c). By 2 August, this low pressure system had eased considerably, although, according to ERA-40 charts (not shown), wind speeds were still sufficient to loft snow into a saltation layer. No ozone sonde was launched on 1 August, so we have no way of knowing the state of the ozone profile during the windier preceding day. Again, however, a high altitude ODE and enhanced $\mathrm{BrO}$ were associated with an atmospheric low pressure system.

In a more recent paper, Frieß et al. (2004) focused on measurements made at Neumayer station in austral spring 1999 and 2000. Their data set included zenith sky DOAS observations of $\mathrm{BrO}$ as well as ozone soundings and they interpreted their results in the context of duration of sea ice contact. From their data they derived a meteorological scenario to describe conditions responsible for depletion in the ozone profile, in which an air mass located over the sea ice is driven south towards the station by an eastward moving depression. They further note that air masses from the sea ice are transported to altitudes of $\sim 4000 \mathrm{~m}$ by advection processes caused by cyclonic activity above the ice covered ocean. We discuss the Frieß et al. paper further below.

Thus, in all previous studies of Antarctic ozone profiles, there is either a stated link to low pressure systems, or a link that can be derived by some additional analysis (using the ERA-40 charts). There are also the first hints of a link between low pressure systems and $\mathrm{BrO}$.

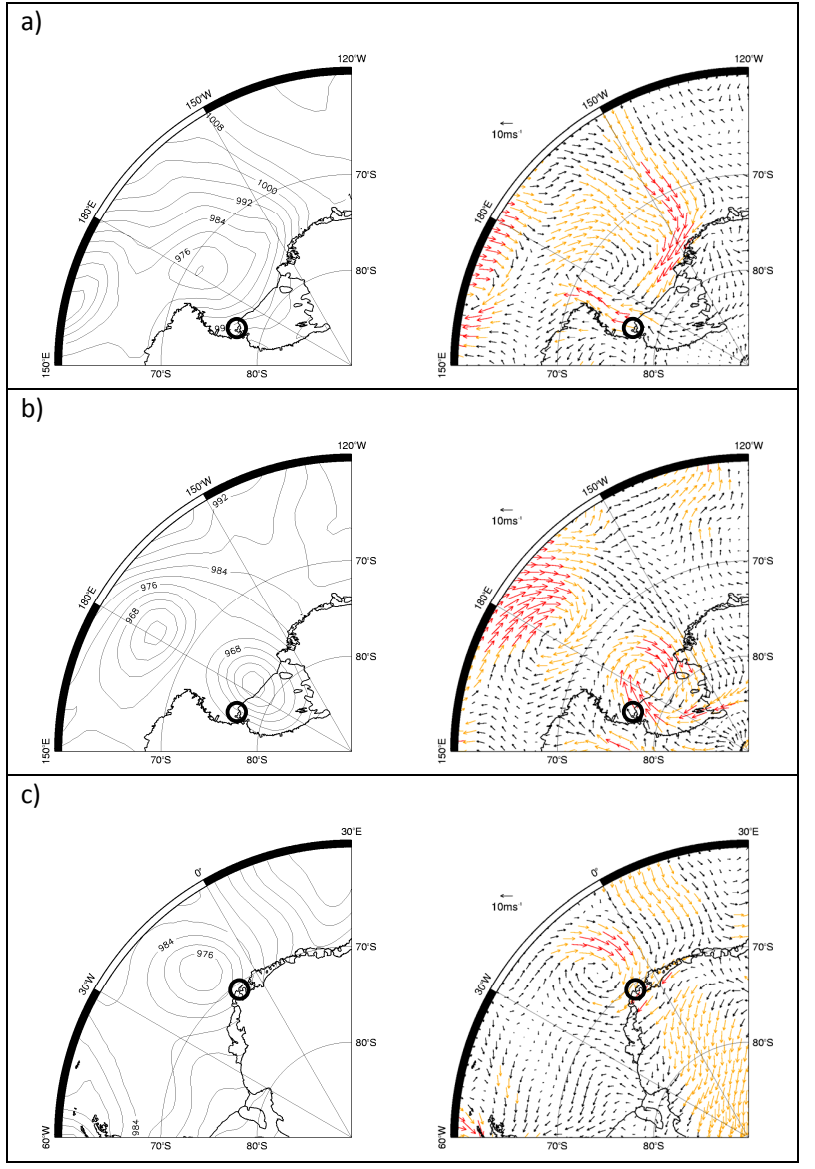

Fig. 18. Charts of mean sea level pressure and 10-m wind vectors coincident with high altitude ODEs discussed in earlier papers (see text for full discussion); (a) Arrival Heights: 23 August 1995 (18:00); (b) Arrival Heights: 14 September 1995 (12:00); (c) Neumayer: 1 August 1995 (12:00). The positions of the stations are marked by the black circles on the plots. Wind speeds are identified as: black $=<8 \mathrm{~ms}^{-1}$; orange $=8$ to $12 \mathrm{~ms}^{-1} ;$ red $=>12 \mathrm{~ms}^{-1}$.

\subsection{Expanding the low pressure system/BrO link}

The papers by Jones et al. (2009) and Yang et al. (2008, 2010) described above raise the idea that atmospheric low pressure systems with sufficient wind speeds to loft saline blowing snow can be a source of bromine to the atmosphere with the potential to deplete tropospheric ozone. Considerable evidence to support this idea can be found within earlier publications. For example, Kreher et al. (1997) note that the initial phase of both $\mathrm{BrO}$ events they observed coincided with high surface winds and blowing snow. Frieß et al. (2004) note that most periods of elevated $\mathrm{BrO}$ were accompanied by strong enhancement in $\mathrm{O}_{4}$ absorption, a diagnostic for tropospheric light path. The authors suggest that, as well as snow drift, it was very likely that the light path enhancement was at least partially caused by sea salt aerosol. 
Importantly, satellite observations of $\mathrm{BrO}$ are available from the GOME (Global Ozone Monitoring Experiment) instrument (Richter et al., 1998; Burrows et al., 1999) from 1996 to 2004, so are available for the period of measurements reported by Frieß et al. (2004). Indeed maps of $\mathrm{BrO}$ total vertical column density (VCD) are presented for a number of days to support the zenith sky DOAS observations reported in the Frieß et al. paper.

We are thus able to combine, for some days, observations of surface ozone, the ozone profile, $\mathrm{BrO}$ from both groundbased zenith sky DOAS and satellite-borne imaging, together with ERA-40 charts of regional meteorology. We refer to data published by Frieß et al. where it exists, and supplement with other sources where necessary. We focus on the three days from the Frieß et al. paper that show the most severe depletion in the surface ozone record.

Firstly, on 9 September 1999, Frieß et al. show that measured surface ozone was $\sim 5 \mathrm{ppbv}$; the ozonesonde launched that day shows that the depletion extended to roughly $1.5 \mathrm{~km}$ altitude; the zenith sky DOAS shows a simultaneous increase in $\mathrm{BrO}$ above background. In addition, we present in Fig. 19a) ERA-40 charts of mean sea level pressure and 10-m wind vectors. They reveal a major low pressure system over the Weddell Sea, with wind speeds in excess of $12 \mathrm{~ms}^{-1}$, that is co-located with a cloud of enhanced $\mathrm{BrO}$ (see Frieß et al., 2004) .

Equally severe depletion is evident in the surface ozone record for 11 September 1999, and again, BrO observed by the DOAS is enhanced. No ozone profile data is presented in the Frieß et al. paper for this day, but the profile is available from the Neumayer web service (http://www.awi.de/en/infrastructure/stations/ neumayer_station/observatories/meteorological_observatory/ data_access/upper_air_soundings/full_vertical_resolution/) (König-Langlo, 2007a). Ozone depletion (not shown) is clear to roughly $3 \mathrm{~km}$ altitude. The GOME map for 11 September 1999 shows an extensive cloud of $\mathrm{BrO}$ to the north of Neumayer, which, according to the ERA-40 charts of mslp and 10-m wind vectors (Fig. 19b), again coincides with a vigorous atmospheric low pressure system.

On 23 September 2000, the third example, Frieß et al. show that surface ozone is depleted to $\sim 5 \mathrm{ppbv}$, while $\mathrm{BrO}$ is enhanced. They further present GOME BrO showing a "hotspot" offshore of Neumayer. The ozone profile, again from the Neumayer web service (König-Langlo, 2007b), shows that ozone depletion extended to roughly $2 \mathrm{~km}$ altitude, and the ERA-40 charts show a low pressure system offshore of Neumayer (see Fig. 19c). This case raises the issue of timing, as the low pressure system of 23 September is the residual of a more vigorous system that was influencing the Neumayer region over the previous two days.

The maps and charts presented in Fig. 19 also show other occasions of coincident low pressure systems and enhanced BrO. These are particularly evident around the Ross Sea, with a very clear example being the $\mathrm{BrO}$ hot spot and low

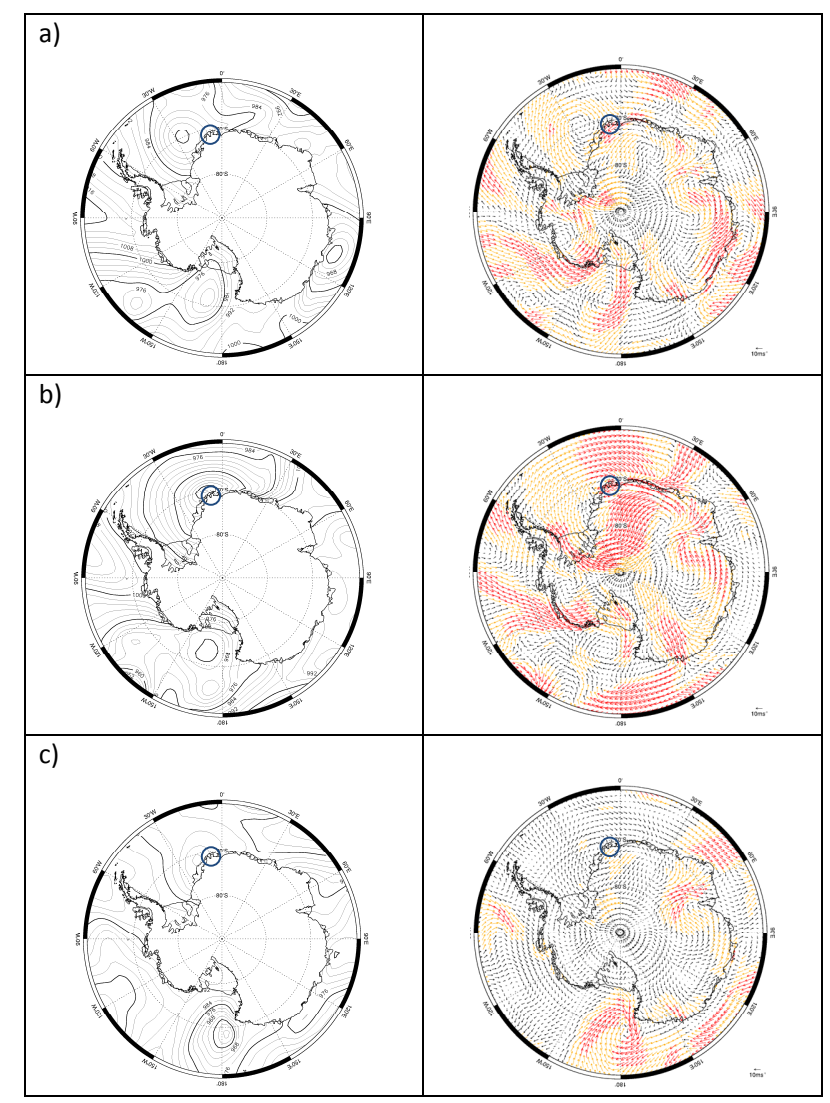

Fig. 19. ERA-40 mean sea level pressure charts and charts of 10$\mathrm{m}$ wind speed vectors that coincide with the high altitude ozone depletion events discussed by Frieß et al. (2004). Maps of BrO from the GOME satellite (see Frieß et al., 2004) show enhanced BrO associated with the low pressure systems shown here. Neumayer is marked by the blue circle on the plots.

pressure system on 23 September (Fig. 19c and Frieß et al., Fig. 13).

Recently it has been shown by Theys et al. (2009) that some enhancement in total $\mathrm{BrO}$ column can be caused by increases in stratospheric $\mathrm{BrO}$ due to a decrease in tropopause height coincident with low surface pressure. For the cases we have discussed here, tropospheric $\mathrm{BrO}$ columns (derived using climatological data validated using ground-based balloon and satellite limb stratospheric $\mathrm{BrO}$ observations) indicate the same structure of $\mathrm{BrO}$ enhancements that are evident in the total column, with tropospheric column amounts up to $8 \times 10^{13} \mathrm{molec} / \mathrm{cm}^{2}$ (N. Theys personal communication, 2010). Given that calculated stratospheric columns at southern high latitudes range from 2.5 to $4.5 \times 10^{13} \mathrm{molec} / \mathrm{cm}^{2}$ (Theys et al., 2009), the BrO hotspots shown in the BrO total column cannot be attributed to the stratosphere and must arise from a tropospheric source. 
It thus appears from this ensemble of data and analyses that high altitude ozone depletion events are associated with atmospheric low pressure systems, but that the association arises as a product of the $\mathrm{BrO}$ generation and concomitant ozone destruction, and not merely as a result of advective processes.

\subsection{Why atmospheric low pressure systems?}

Satellite imagery and high resolution meteorological analyses reveal that there is a spectrum of atmospheric low pressure systems in high southern latitudes from the mesoscale (less than $1000 \mathrm{~km}$ horizontal resolution) "polar lows" to synoptic-scale depressions with a diameter of 2000 to $3000 \mathrm{~km}$. Polar lows tend to have a lifetime of less than $24 \mathrm{~h}$, but they can be very vigorous with winds in excess of gale force (Rasmussen and Turner, 2003). The synopticscale lows usually have a lifetime of several days, although the detailed structure of the systems can change considerably during its evolution.

On satellite imagery most depressions are characterised by having the cloud organised into comma-shaped or spiraliform bands, which often define the boundaries between air masses. The imagery also shows that many polar lows develop in the southerly air flow to the west of a large depression during cold air outbreaks.

By definition, all low pressure systems are associated with low level convergence and general ascent, with divergence at upper levels. However, the cloud bands indicate areas of particularly marked ascent, and models and radar data have shown that the air flow in these areas consists of a number of "conveyor belts", streams of rapid advection with slope, and not just simple ascent up a frontal surface. A warm conveyor takes air from the surface to the upper levels of the cyclonic system, the air being replaced by the descending cold air. Larger depressions can have ascent from the surface to the upper troposphere.

Polar depressions thus provide the conditions for high wind speeds, and thereby blowing snow, at ground level, and a mechanism to transport processed air to considerable altitudes.

While blowing snow appears to contribute to the mechanism for ODEs at high wind speeds, this mechanism depends critically on there being sufficient salinity in the snow. Simpson et al. (2007) reported that saline snow was ubiquitous on first-year sea ice and contained significant quantities of salts necessary for halogen activation. Around the coast of Antarctica, the seasonal variation in sea ice extent is enormous, ranging from the annual maximum (roughly 18 million $\mathrm{km}^{2}$ ) to the minimum (roughly 2.5 million $\mathrm{km}^{2}$ ). There is thus an enormous reservoir of first-year sea ice around Antarctica with the potential for halogen activation.

\subsection{What about the Arctic?}

An obvious question that arises at this point is whether this mechanism also operates in the Arctic. The Arctic and Antarctic sea ice zones are very different. Geographically, one is a frozen ocean surrounded by land masses while the other is peripheral to a large continent. As a result of the differing topography, there are considerable differences in meteorology in the two polar regions. The frozen Arctic Ocean is dominated by high pressure systems while the sea ice zone around Antarctica is subject to repeated lows. Early Arctic work by Hopper et al. (1998) linked high pressure systems with ozone depletion to $200-400 \mathrm{~m}$ altitude and sustained surface ozone depletion within the sea ice zone. More recent measurements, also made within the Arctic sea ice zone, have also found sustained surface ozone loss during extended periods of high pressure (Jacobi et al., 2006; Bottenheim et al., 2009). Further, a recent paper (Jacobi et al., 2010) has found that low pressure systems moving northwards into the Central Arctic from mid-latitudes are associated with transitions to higher mixing ratios of ozone, more typical of remote background sites, and that ozone mixing ratios are strongly negatively correlated to atmospheric pressure during such events. This is the opposite conclusion to our findings for Antarctica, and highlights the existence of critical differences between the Arctic and Antarctic atmospheric systems.

However, although we have not explored in any detail the potential for low pressure systems in the Arctic to drive high altitude ozone depletion or major enhancement to the $\mathrm{BrO}$ column, it appears that it can occur. A particularly striking example can be found between 25 and 28 March 2007, during which time satellite observations of both total and tropospheric column $\mathrm{BrO}$ from the SCIAMACHY instrument show an enormous area of enhanced $\mathrm{BrO}$ covering approximately half of the Arctic Ocean basin (Begoin et al., 2010). At the same time, ERA-40 meteorological charts show a huge and windy depression, not only covering the same region, but propagating eastward in tandem with the $\mathrm{BrO}$ (see Begoin et al., 2010). We derived 10-m wind speed vectors for this event and found that wind speeds were indeed sufficient for lofted and blowing snow (plots not shown). Such a meteorological situation is unusual in the Arctic, so how important this mechanism is for ozone depletion, particularly to high altitudes, and for the production and export of halogens from the Arctic, remains an open question and goes well beyond the scope of this paper. Given the changing state of the Arctic, and projected future changes, however, it seems important to assess the contribution and how this might develop as the Arctic warms and coverage of first year sea ice increases. 


\section{Summary and conclusions}

This paper has probed low- and high-altitude features of ozone depletion events using two different profiling methods as well as a variety of supporting data. The results suggest a number of generalised features.

From the tethersonde data, the low altitude ODEs were highly constrained by the complex layering within the troposphere and were often confined within an extremely shallow lowest layer. Satellite images of $\mathrm{BrO}$ at the time of the tethersonde launches show no significant enhancement to the $\mathrm{BrO}$ column. If we associate (as a first pass) enhanced $\mathrm{BrO}$ with depleted ozone, then this result suggests that the impact on the wider atmosphere from Antarctic ODEs generated under low wind speeds and quiescent conditions is limited. It may be that their value lies more in providing constrained case studies against which mechanistic understanding can be tested. Numerical model studies that aim to reproduce ODEs observed under low wind speeds will need to consider the role played by small scale features in boundary layer and the resultant influence on ozone mixing ratios.

The results from the 1987 ozonesonde programme suggest that in Antarctica, profiles of ozone depletion to significant altitude are associated with high wind speed, low pressure systems. We have shown, further, that Antarctic depressions are also associated with enhanced BrO. Previous authors have suggested that transport into the free troposphere of air depleted in ozone may have implications for the regional radiative budget and that this same transport may have significant implications for the budget of halogens in the free troposphere (e.g. Roscoe et al., 2001; Frieß et al., 2004). Our analyses strongly suggest that, when considering the wider implications of Antarctic tropospheric ODEs, it is the large, energetic low pressure systems that appear to be able to both process larger air masses and export them to lower latitudes. Such events are thus likely to drive the regional (or wider) impact of ODEs around Antarctica. The degree to which the free troposphere is altered by ODE chemistry in the future will therefore also be strongly influenced by any changes that may occur to such meteorological systems.

To test these ideas about high altitude Antarctic ODEs and their association with atmospheric depressions, a programme of high temporal resolution ozonesonde launches, or observations with an ozone DIAL (Differential Absorption Lidar), would be required. Thus far, the frequency of sonde launches limits our conclusions to the broad-scale because of the mismatch in timing between the occurrence of low pressure systems and the launch of the ozonesonde. Higher temporal resolution data would enable hypotheses to be tested in numerical models and detailed understanding of the mechanisms involved to be developed and confirmed. A systematic study of Arctic data is also now timely.
Acknowledgements. The authors would like to thank the 1987 and 2007 Halley overwintering teams who made the sonde measurements and Russ Ladkin (BAS) for providing the meteorological sonde and its Labview logging software. We thank B. G. Gardiner for providing the 1987 balloon-borne ozone sonde data, J. D. Shanklin for discussions regarding the 1987 measurement methodology, and Tom Brooke for processing potential temperature data. We are very grateful to John Turner for his input to the section about polar low pressure systems, and also to Nicolas Theys for discussions and calculations regarding the tropospheric $\mathrm{BrO}$ column for case studies considered in this paper. This study is part of the British Antarctic Survey Polar Science for Planet Earth Programme. It was funded by the Natural Environment Research Council.

Edited by: J. W. Bottenheim

\section{References}

Anderson, P. S.: Evidence for an Antarctic winter coastal polynya, Ant. Sci., 5(2), 221-226, 1993.

Anderson, P. S.: Fine-scale structure observed in a stable atmospheric boundary layer by Sodar and kite-borne tethersonde, Bound.-Lay. Meteorol., 107(2), 323-351, 2003.

Anderson, P. S. and Neff, W. D.: Boundary layer physics over snow and ice, Atmos. Chem. Phys., 8, 3563-3582, doi:10.5194/acp-83563-2008, 2008.

Anlauf, K. G., Mickle, R. E., and Trivett, N. B. A.: Measurements of ozone during Polar Sunrise Experiment 1992, J. Geophys. Res., 99(D12), 25345-25353, 1994.

Begoin, M., Richter, A., Weber, M., Kaleschke, L., Tian-Kunze, X., Stohl, A., Theys, N., and Burrows, J. P.: Satellite observations of long range transport of a large $\mathrm{BrO}$ plume in the Arctic, Atmos. Chem. Phys., 10, 6515-6526, doi:10.5194/acp-10-65152010, 2010.

Bottenheim, J. W., Dibb, J. E., Honrath, R. E., and Shepson, P. B.: An introduction to the ALERT 2000 and SUMMIT 2000 Arctic research studies, Atmos. Environ., 36, 2467-2469, 2002.

Bottenheim, J. W., Netcheva, S., Morin, S., and Nghiem, S. V.: Ozone in the boundary layer air over the Arctic Ocean: measurements during the TARA transpolar drift 20062008, Atmos. Chem. Phys., 9, 4545-4557, doi:10.5194/acp-9-4545-2009, 2009.

Bovensmann, H., Burrows, J. P., Buchwitz, M., Frerick, J., Noël, S., and Rozanov, V. V.: SCIAMACHY - Mission objectives and measurement modes, J. Atmos. Sci., 56(2), 127-150, 1999.

Burrows, J. P., Weber, M., Buchwitz, M., Rozanov, V., LadstätterWeißenmayer, A., Richter, A., DeBeek, R., Hoogen, R., Bramstedt, K., Eichmann, K.-U., Eisinger, M., and Perner, D.: The Global Ozone Monitoring Experiment (GOME): Mission concept and first scientific results, J. Atmos. Sci., 56, 151-175, 1999.

Culf, A. D.: Acoustic Sounding of the Atmospheric Boundary Layer at Halley, Antarctica, Ant. Sci., 1, 363-372, 1989.

Fan, S.-M. and Jacob, D. J.: Surface ozone depletion in Arctic spring sustained by bromine reactions on aerosols, Nature, 359, 522-524, 1992.

Frieß, U., Hollwedel, J., Konig-Langlo, G., Wagner, T., and Platt U.: Dynamics and chemistry of tropospheric bromine explosion 
events in the Antarctic coastal region, J. Geophys. Res., 109, D06305, doi:10.1029/2003JD004133, 2004.

Galperin, B., Sukoriansky, S., and Anderson, P. S.: On the critical Richardson number in stably stratified turbulence, Atmos. Sci. Lett., 8, 65-69, doi:10.1002/asl.153, 2007.

Gardiner, B. G. and Farman, J. C.: Results of the 1987 ozonesonde programme at Halley Bay, Antarctica, British Antarctic Survey, Cambridge, ISBN 085665128 1, 1988.

Helmig, D., Oltmans, S., Carlson, D., Lamarque, J.-F., Jones, A. E., Labuschagne, C., Anlauf, K., and Hayden, K.: A review of surface ozone in the polar regions, Atmos. Environ., 41, 51385161, doi:10.1016/j.atmosenv.2006.09.053, 2007.

Hopper, J. F. and Hart, W.: Meteorological aspects of the 1992 Polar Sunrise Experiment, J. Geophys. Res., 99, 25315-25328, 1994.

Hopper, J. F., Barrie, L. A., Silis, A., Hart, W., Gallant, A. J., and Dryhout, H.: Ozone and meteorology during the 1994 Polar Sunrise Experiment, J. Geophys. Res., 103, 1481-1492, 1998.

Jacobi, H.-W., Kaleschke, L., Richter, A., and Rozanov, A.: Observations of a fast ozone loss in the marginal ice zone of the Arctic Ocean, J. Geophys. Res., 111, D15309, doi:10.1029/2005JD006715, 2006.

Jacobi, H.-W., Morin, S., and Bottenheim, J. W.: Observation of widespread depletion of ozone in the springtime boundary layer of the Central Arctic linked to mesoscale synoptic conditions, J. Geophys. Res., doi:10.1029/2010JD013940, in press, 2010.

Jones, A. E., Anderson, P. S., Wolff, E. W., Turner, J., Rankin, A. M., and Colwell, S. R.: A role for newly-forming sea ice in springtime polar tropospheric ozone loss? Observational evidence from Halley station, Antarctica, J. Geophys. Res., 111, D08306, doi:10.1029/2005JD006566, 2006.

Jones, A. E., Wolff, E. W., Salmon, R. A., Bauguitte, S. J.-B., Roscoe, H. K., Anderson, P. S., Ames, D., Clemitshaw, K. C., Fleming, Z. L., Bloss, W. J., Heard, D. E., Lee, J. D., Read, K. A., Hamer, P., Shallcross, D. E., Jackson, A. V., Walker, S. L., Lewis, A. C., Mills, G. P., Plane, J. M. C., Saiz-Lopez, A., Sturges, W. T., and Worton, D. R.: Chemistry of the Antarctic Boundary Layer and the Interface with Snow: an overview of the CHABLIS campaign, Atmos. Chem. Phys., 8, 3789-3803, doi:10.5194/acp-8-3789-2008, 2008.

Jones, A. E., Anderson, P. S., Begoin, M., Brough, N., Hutterli, M. A., Marshall, G. J., Richter, A., Roscoe, H. K., and Wolff, E. W.: $\mathrm{BrO}$, blizzards, and drivers of polar tropospheric ozone depletion events, Atmos. Chem. Phys., 9, 4639-4652, doi:10.5194/acp-94639-2009, 2009.

King, J. C.: Low-level wind profiles at an Antarctic coastal station, Ant. Sci., 1, 169-178, 1989.

King, J. C.: Control of near-surface winds over an Antarctic ice shelf, J. Geophys. Res., 98, 12949-12953, 1993.

Komhyr, W. D.: Electrochemical concentration cells for gas analysis, Ann. Geophys., 25, 203-210, 1969, http://www.ann-geophys.net/25/203/1969/.

Komhyr, W. D.: Operations Handbook - Ozone measurements t $40 \mathrm{~km}$ altitude with Model 4A electrochemical concentrations cell (ECC) ozonesondes (used with 1680-MHz radiosondes),NOAA Technical Memorandum ERL ARL-149, Air Resources Laboratory, Maryland, 1986.

Komhyr, W. D., Barnes, R. A., Brothers, G. B., Lathrop, J. A., and Opperman, D. P.: Electrochemical concentration cell ozonesonde performance evaluation during STOIC 1989, J. Geo- phys. Res., 100, 9231-9244, 1995.

König-Langlo, G., King, J. C., and Pettré, P.: Climatology of the three coastal Antarcic stations Dumont d'Urville, Neumayer, and Halley, J. Geophys Res., 103, 10947-10959, 1998.

König-Langlo, G.: Radiosonde measurements from Neumayer Station (1999-09). Alfred Wegener Institute for Polar and Marine Research, Bremerhaven, doi:10.1594/PANGAEA.674441, available online at: http://doi.pangaea.de/10.1594/PANGAEA. 674441, 2007a.

König-Langlo, G.: Radiosonde measurements from Neumayer Station (2000-09). Alfred Wegener Institute for Polar and Marine Research, Bremerhaven, doi:10.1594/PANGAEA.674453, available online at: http://doi.pangaea.de/10.1594/PANGAEA. 674453, 2007b.

Kreher, K., Johnston, P. V., Wood, S. W., Nardi, B., and Platt, U.: Ground-based measurements of tropospheric and stratospheric BrO at Arrival heights, Antarctica, Geophys. Res. Lett., 24(23), 3021-3024, 1997.

Lehrer, E., Hönninger, G., and Platt, U.: A one dimensional model study of the mechanism of halogen liberation and vertical transport in the polar troposphere, Atmos. Chem. Phys., 4, $2427-$ 2440, doi:10.5194/acp-4-2427-2004, 2004.

Mann, G. W., Anderson, P. S., and Mobbs, S. D.: Profile measurements of blowing snow at Halley, Antarctica, J. Geophys. Res. 105(D19), 24491-24508, 2000.

Morin, S., Hönniger, G., Staebler, R. M., and Bottenheim, J. W.: A high time resolution study of boundary layer ozone chemistry and dynamics over the Arctic Ocean near Alert, Nunavut, Geophys. Res. Lett., 32, L08809, doi:10.1029/2004GL022098, 2005.

Neuman, J. A., Nowak, J. B., Huey, L. G., Burkholder, J. B., Dibb, J. E., Holloway, J. S., Liao, J., Peischl, J., Roberts, J. M., Ryerson, T. B., Scheuer, E., Stark, H., Stickel, R. E., Tanner, D. J., and Weinheimer, A.: Bromine measurements in ozone depleted air over the Arctic Ocean, Atmos. Chem. Phys. Discuss., 10, 38273860, doi:10.5194/acpd-10-3827-2010, 2010.

Pöhler, D., Vogel, L., Friess, U., and Platt, U.: Observation of halogen species in the Amundsen Gulf, Arctic, by active long-path differential optical absorption spectroscopy, P. Natl. Acad. Sci., 107(15), 6582-6587, doi:10.1073/pnas.0912231107, 2010.

Rankin, A. M. and Wolff, E. W.: Aerosol profiling using a tethered balloon in coastal Antarctica, J. Atmos. Ocean. Tech., 19, 19781985, 2002.

Rasmussen, E. A. and Turner, J. T.: Polar Lows: Mesoscale weather systems in the polar regions, Cambridge University Press, Cambridge, 612 pp., 2003.

Renfrew, I. A., King, J. C., and Markus, T.: Coastal polynyas in the southern Weddell Sea: Variability of the surface energy budget, J. Geophys. Res., 107(C6), 3063, doi:10.1029/2000JC000720, 2002.

Richter, A., Wittrock, F., Eisinger, M., and Burrows, J. P.: GOME observations of tropospheric BrO in Northern Hemispheric spring and summer 1997, Geophys. Res. Lett., 25, 2683 2686, 1998.

Ridley, B. A., Atlas, E. L., Montzka, D. D., Browell, E. V., et al.: Ozone Depletion Events Observed in the High Latitude Surface Layer During the TOPSE Aircraft Program, J. Geophys. Res., 108, 8356, doi:10.1029/2001JD001507, 2003.

Roscoe, H. K., Kreher, K., and Frieß, U.: Ozone loss episodes in the free Antarctic troposphere, suggesting a possible climate feed- 
back, Geophys. Res. Lett., 28(15), 2911-2914, 2001.

Saiz-Lopez, A., Mahajan, A. S., Salmon, R. A., Bauguitte, S. J.B., Jones, A. E., Roscoe, H. K., and Plane, J. M. C.: Boundary layer halogens in coastal Antarctica, Science 317, 348-351, doi:10.1126/science.1141408, 2007.

Saiz-Lopez, A., Plane, J. M. C., Mahajan, A. S., Anderson, P. S., Bauguitte, S. J.-B., Jones, A. E., Roscoe, H. K., Salmon, R. A., Bloss, W. J., Lee, J. D., and Heard, D. E.: On the vertical distribution of boundary layer halogens over coastal Antarctica: implications for $\mathrm{O}_{3}, \mathrm{HO}_{\mathrm{x}}, \mathrm{NO}_{\mathrm{x}}$ and the $\mathrm{Hg}$ lifetime, Atmos. Chem. Phys., 8, 887-900, doi:10.5194/acp-8-887-2008, 2008.

Simpson, W. R., von Glasow, R., Riedel, K., Anderson, P., Ariya, P., Bottenheim, J., Burrows, J., Carpenter, L. J., Frieß, U., Goodsite, M. E., Heard, D., Hutterli, M., Jacobi, H.-W., Kaleschke, L., Neff, B., Plane, J., Platt, U., Richter, A., Roscoe, H., Sander, R., Shepson, P., Sodeau, J., Steffen, A., Wagner, T., and Wolff, E.: Halogens and their role in polar boundary-layer ozone depletion, Atmos. Chem. Phys., 7, 4375-4418, doi:10.5194/acp-74375-2007, 2007.

Solberg, S., Schmidbauer, N., Semb, A., and Stordal, F.: Boundary layer ozone depletion as seen in the Norwegian arctic in spring, J. Atmos. Chem., 23, 301-332, 1996.

Strong, C., Fuentes, J. D., Davis, R. E., and Bottenheim, J. W.: Thermodynamic attributes of Arctic boundary layer ozone depletion, Atmos. Environ., 36, 2641-2652, 2002.

Stull, R. B.: An Introduction to Boundary Layer Meteorology, Kluwer Academic Publishers, Dordrecht, 670 pp., 1988.

Tackett, P. J., Cavender, A. E., Keil, A. D., Shepson, P. B., Bottenheim, J. W., Morin, S., Deary, J., Steffen, A., and Doerge, C.: A study of the vertical scale of halogen chemistry in the Arctic troposphere during Polar Sunrise at Barrow, Alaska, J. Geophys. Res., 112, D07306, doi:10.1029/2006JD007785, 2007.

Tang, T. and McConnell, J. C.: Autocatalytic release of bromine from Arctic snow pack during polar sunrise, Geophys. Res. Lett., 23, 2633-2636, 1996.
Tarasick, D. W. and Bottenheim, J. W.: Surface ozone depletion episodes in the Arctic and Antarctic from historical ozonesonde records, Atmos. Chem. Phys., 2, 197-205, doi:10.5194/acp-2197-2002, 2002.

Theys, N., Van Roozendael, M., Errera, Q., Hendrick, F., Daerden, F., Chabrillat, S., Dorf, M., Pfeilsticker, K., Rozanov, A., Lotz, W., Burrows, J. P., Lambert, J.-C., Goutail, F., Roscoe, H. K., and De Mazière, M.: A global stratospheric bromine monoxide climatology based on the BASCOE chemical transport model, Atmos. Chem. Phys., 9, 831-848, doi:10.5194/acp-9-831-2009, 2009.

Uppala, S. M., Kaallberg, P. W., Simmonds, A. J. , et al.: The ERA40 re-analysis, Q. J. Roy, Meteorol. Soc., 131(612), 2961-3012, 2005.

Vogt, R., Crutzen, P. J., and Sander, R.: A mechanism for halogen release from sea-salt aerosol in the remote marine boundary layer, Nature, 383, 327-330, 1996.

Wagner, T., Ibrahim, O., Sinreich, R., Frieß, U., von Glasow, R., and Platt, U.: Enhanced tropospheric BrO over Antarctic sea ice in mid winter observed by MAX-DOAS on board the research vessel Polarstern, Atmos. Chem. Phys., 7, 3129-3142, doi:10.5194/acp-7-3129-2007, 2007.

Wessel, S., Aoki, S., Winkler, P., Weller, R., Herber, A., Gernandt, H., and Schrems, O.: Tropospheric ozone depletion in polar regions: A comparison of observations in the Arctic and Antarctic, Tellus B, 50, 34-50, 1998.

Yang, X., Pyle, J. A., and Cox, R. A.: Sea salt aerosol production and bromine release: Role of snow on sea ice, Geophys. Res. Lett., 35, L16815, doi:10.1029/2008GL034536, 2008.

Xin Yang, Pyle, J. A., Cox, R. A., Theys, N., and Van Roozendael, M.: Snow-sourced bromine and its implications for polar tropospheric ozone, Atmos. Chem. Phys. Discuss., 10, 8135-8164, doi:10.5194/acpd-10-8135-2010, 2010. 